Petar Puhmajer

Bernarda Ratančić

Petar Puhmajer

Bernarda Ratančić

Hrvatski restauratorski zavod

Odsjek za istraživanje i

dokumentaciju nepokretne baštine ppuhmajer@h-r-z.hr

bratancic@h-r-z.hr

Izvorni znanstveni rad/

Original scientific paper

Primljen/Received: 24. 06. 2015

UDK:

726.71.025:272-789](497.5 Lepoglava)

DOI:

http://dx.doi.org/10.17018/portal.2015.12

\section{Ljetni refektorij pavlinskog samostana} u Lepoglavi - nastanak, razaranje i ponovno otkrivanje

SAŽETAK: U članku se obrađuje kronologija nastanka i sudbina prostorije ljetnog refektorija u nekadašnjem pavlinskom samostanu u Lepoglavi. Refektorij je formiran kao najveća samostanska prostorija prilikom izgradnje zapadnog krila u 17. stoljeću, a u 18. stoljeću je bogato opremljen zidnim slikama i štukaturom. Prenamjenom samostana u kaznionicu u 19. stoljeću počinje njegova dugogodišnja degradacija, ponajprije korištenjem u neprimjerene kaznioničke svrhe, a osobito rušenjem svoda u potresu 1880. godine. U to se doba također uočavaju prva nastojanja za njegovo očuvanje, u smislu dokumentiranja, istraživanja i valorizacije, u čemu se ističe djelovanje Ivana Kukuljevića Sakcinskog i Izidora Kršnjavog te osobito slikarski rad Ferdinanda Quiquereza koji je izradio kopiju cijele dekoracije refektorija na kartonima u akvarelu. Refektorij, nadalje, teško stradava u Drugom svjetskom ratu, kad zbog rušenja gornjih etaža zapadnog krila samostana nekoliko godina ostaje nenatkriven. Do početka ovog stoljeća držalo se da ništa od nekadašnje dekorativne opreme refektorija nije sačuvano, međutim, konzervatorskim istraživanjima pronađeni su naslikani medaljoni s likovima pavlinskih dobrotvora na istočnom zidu, naslikane lunete na sjevernom i južnom zidu, kao i zazidana grota sa štuko kipovima. U članku se, osim rezultata konzervatorskih istraživanja, analiziraju i smjernice za obnovu.

KLJUČNE RIJEČI: arhitektura, Lepoglava, pavlinski samostan, ljetni refektorij, 18. stoljeće, barok, razaranje, obnove, konzervatorska istraživanja
$\mathrm{S}$ amostanski su refektoriji tijekom cijele povijesti novovjekovne arhitekture bili bogato ukrašavani, posebno u baroknom razdoblju, kad u njima nastaju izuzetno dekorativne kompozicije zidnih slika i štukatura. Kompleks pavlinskog samostana u Lepoglavi bio je opremljen kiparskim i slikarskim djelima, u čemu su se isticale važne samostanske prostorije, poput knjižnice, ljekarne te čak dva refektorija, ljetni i zimski. Oprema tih prostorija znatnim je dijelom nepovratno nestala. Kad se nakon silnih razaranja i devastacije samostanskog sklopa prišlo konzervatorskim istraživanjima, bila je to prilika da se utvrdi što je od izvorne opreme sačuvano i koje su mogućnosti njezine obnove.
O ljetnom refektoriju lepoglavskog samostana pisalo se u više navrata, pri čemu je pozornost u najvećoj mjeri bila usmjerena na zidne oslike. Oslike su u 19. stoljeću prvi spominjali Ivan Kukuljević Sakcinski, ${ }^{1}$ Ivan Krstitelj Krapac $^{2}$ i Šime Ljubić, ${ }^{3}$ a detaljan pregled iznio je Izidor Kršnjavi, ${ }^{4}$ neposredno prije rušenja svoda 1880 . Kasniji autori, poput Roberta Kauka ${ }^{5}$ i Gjure Szabe ${ }^{6}$ također su pisali o osliku lepoglavskog refektorija, uglavnom se referirajući na prethodne istraživače, s obzirom na to da je dotad svod već bio uništen. Detaljniju znanstvenu analitiku ljetnog refektorija $u$ dva je navrata izradila Marija Mirković, ${ }^{7}$ a u novije vrijeme i Tomislav Pugelnik. Pugelnik donosi iscrpnu analizu svih prizora, uz daljnje ikono- 


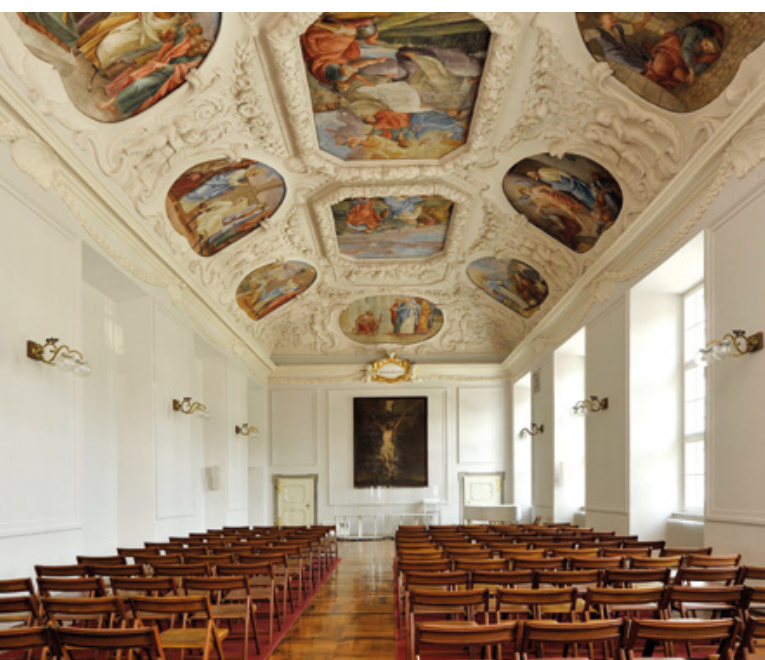

1. Ljetni refektorij minoritskog samostana u Ptuju sa sličnim konceptom oblikovanja prostora i dekoracije kao u nekadašnjem ljetnom refektoriju u Lepoglavi (HRZ, snimila N. Vasić, 2015.) Summer refectory of the Minorite Monastery in Ptuj with the design resembling that of the former summer refectory in Lepoglava (Croatian Conservation Institute Photo Archive, photo by N. Vasić, 2015)

grafsko prepoznavanje likova, a prvi put objavljuje i veliki akvarel Ferdinanda Quiquereza iz 1878. s cjelovitim prikazom zidne i svodne dekoracije prije njezina uništenja. ${ }^{8}$ Navedeni autori zaslužni su za to što je izvorni izgled lepoglavskog refektorija relativno dobro poznat.

S velikom sigurnošću može se rekonstruirati izgled refektorija, kakav je postojao od pavlinskih vremena 18 . stoljeća pa do velikog potresa 188 o. Izdužena pravokutna prostorija bila je smještena $u$ prizemlju zapadnog krila samostana, položena u smjeru sjever-jug, osvijetljena sa šest prozora na zapadnom zidu te dvama na istočnom, prema hodniku. Imala je tek jedan ulaz, kojemu je sa strane hodnika bio reprezentativan portal. Prostorija je bila nadsvođena bačvastim svodom sa susvodnicama, a svod i zidovi bili su u 18. stoljeću prekriveni štukaturom i oslikom. Tako su se na istočnom zidu, u lunetama ispod susvodnica, nalazili pravokutni, segmentno zaključeni medaljoni s portretima pavlinskih velikana i dobrotvora, redom od sjevera prema jugu: Pavla Ivanovića, Emerika Esterhazyja, Ivaniša Korvina i Hermana Celjskog. Na sjevernom je zidu bila velika, polukružno zaključena luneta s prikazom Papa pavlinima potvrđuje pravila reda, a na južnom luneta s likovima sv. Augustina s lijeve strane i sv. Jeronima s desne, dok je u sredini bila kiparski oblikovana niša, točnije grota sa štuko kipovima sv. Pavla i sv. Antuna te s raspelom u sredini. Na svodu su, na središnjem dijelu, bili naslikani prikazi triju novozavjetnih gozbi, a u susvodnicama, unutar trolisnih medaljona, prizori iz života sv. Pavla i Antuna. Na donjem dijelu svoda, između susvodnica, nalazili su se veliki portreti važnih članova pavlinskog reda, među kojima su bili ponovo Pavao Ivanović i Emerik Esterhazy, zatim provincijal Bene- dikt II., biskup Martin Borković, prior Gašpar Malečić i drugi. Na rubovima svoda uz kraće stranice prostorije bili su bogato oslikani vijenci s voćem. Svodne slike bile su okružene elaboriranom štuko dekoracijom, koja je prekrivala sve slobodne površine svoda. Ispod svodnih peta, na bočnim zidovima, $u$ žbuci su bili formirani dekorativni lambrekeni u obliku povijenog slova V. Cijela kompozicija zidnog oslika sa štukaturom činila je osebujan prostor visoke ambijentalne i umjetničke vrijednosti te se vidi da je bio pomno osmišljen i sadržajno koncipiran. Kako je mogao izgledati u stvarnosti, dočarava danas sačuvan prostor ljetnog refektorija minoritskog samostana u Ptuju (sl. 1), gdje nalazimo vrlo sličan koncept štuko dekoracije i oslikanih polja na svodu, koji nastaje nekoliko desetljeća prije lepoglavskog (1693.). ${ }^{9}$

Ovom prilikom nećemo ulaziti u ikonografsku analizu, atribuiranje i datiranje zidnog oslika, budući da je ono u postojećoj literaturi već detaljno obrađeno. Prije svega ćemo razmotriti arhitektonsku povijest refektorija, njegov nastanak i postupno stradavanje te recentna konzervatorsko-restauratorska istraživanja kojima su iznova otkriveni tragovi njegova uređenja.

\section{Zapisi o refektoriju u doba pavlina}

Zgrada lepoglavskog samostana građena je sukcesivno od 1650. do 1673 . godine. ${ }^{10}$ Gradnja je započeta 1650 . postavljanjem kamena temeljca za novu sakristiju „na mjestu postojeće“" "što znači da je najprije građeno istočno krilo samostana. ${ }^{12}$ Ono je dovršeno i useljeno do 1656 ., a istovremeno je počela gradnja sjevernoga krila, koje je dovršeno 1663 . godine. ${ }^{13}$ Početak gradnje zapadnog krila se ne navodi, ali se dovršetak spominje oko 1673 . godine. ${ }^{14}$

Pavlinski kroničar Ivan Krištolovec piše u 18. stoljeću da su u Lepoglavi "dvije velike blagovaonice: jedna ljetna, koja je okrenuta prema zalazećem suncu, druga zimska, koja je okrenuta prema istoku i sjeveru. Obje su ukrašene lijepim svodom i raznovrsnim freskama i slikama. Iz svake blagovaonice, koja u sebi ima sve nužne potrepštine, može se prikladnim stubištem sići u podrum, a uz njih stoje i izdvojene kuhinje u kojima se priprema hrana za oce, goste, te za samostansku služinčad. “15 Nije posve jasno zbog čega je ljetni refektorij bio smješten na osunčanoj, zapadnoj strani, a zimski na hladnoj, sjeverozapadnoj strani, umjesto obratno, ${ }^{16}$ no da je doista bilo tako, svjedoči i tlocrt samostana iz Spomenice župe Lepoglava, na kojem je jasno naznačen Refectorium aestivale na zapadnoj strani te Refectorium hÿemale na istočnoj. Na nacrtima iz sredine 19. stoljeća, o kojima će biti riječi dalje $u$ tekstu, oba se refektorija jasno vide $u$ gotovo izvornom prostornom rasporedu.

Osim Krištolovca, rani zapis o ljetnom refektoriju donosi i pavlinski pisac Nikola Benger koji navodi da je 1722. grof Ivan Pethö dao ukrasiti refektorij svodom sa štukaturom (celaturae gypsariae) i svetačkim slikama, posebno s 


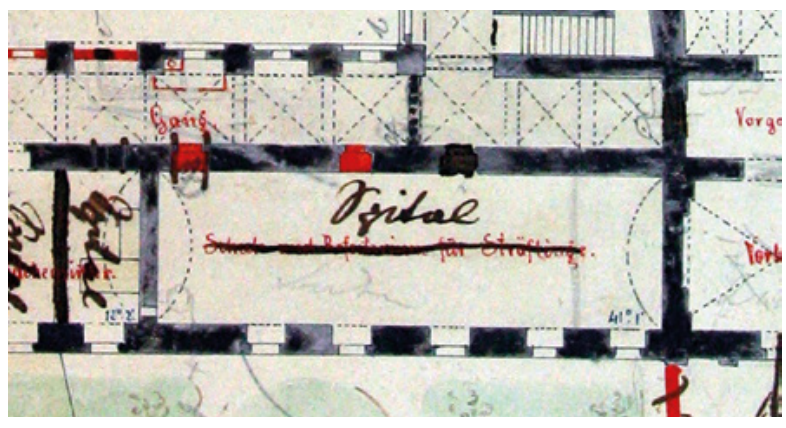

2. Nacrt lepoglavskog samostana nepoznatog autora iz oko 1850. s detaljnim prikazom nekadašnjeg ljetnog refektorija. Crvenom bojom naznačene su planirane adaptacije u to vrijeme, a crnom bojom adaptacije izvedene poslije (planoteka Uprave za zaštitu kulturne baštine)

Detail of the Lepoglava monastery plan dated to cca 1850, showing the former summer refectory. Red marks the planned renovation and black marks the interventions made in the later period (Ministry of Culture, Directorate for the Protection of Cultural Heritage)

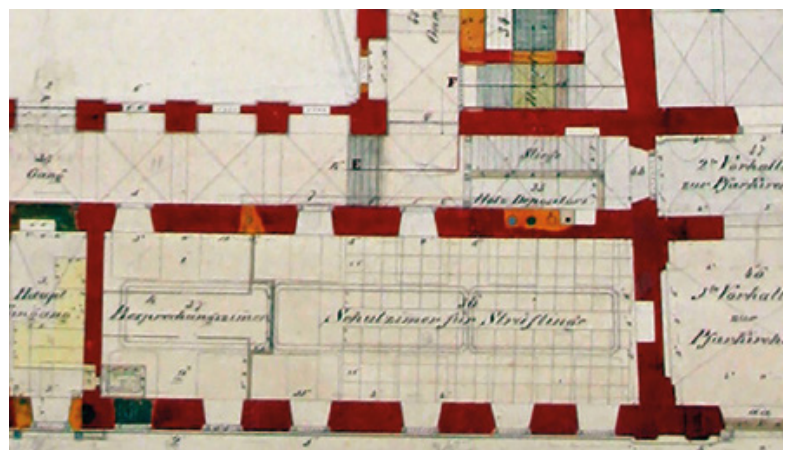

4. Detalj nacrta Johanna Polivke iz 1852. s prikazom nekadašnjeg ljetnog refektorija (planoteka Uprave za zaštitu kulturne baštine) Detail of the Lepoglava monastery plan from 1852, by Johann Polivka, showing the former summer refectory. (Ministry of Culture, Directorate for the Protection of Cultural Heritage)

temom čuda sv. Pavla. ${ }^{17}$ Jedanaest godina poslije, tj. 1733. navodi se da je refektorij „obnovljen novim slikama na svodu i lukovima“ te da mu je postavljen novi mramorni pod, djelomično zaslugom oca generala Stjepana Demšića, a dijelom provincijala Andrije Mužara. ${ }^{18}$

Oba zapisa ostavljaju nekoliko dvojbi o nastanku svoda i ukrasa. Prvu dvojbu otvara riječ celaturae koja u načelu označava strop, a ne svod, iako se u govornom jeziku i danas zamjenjuju ta dva pojma. Štoviše, zapisi upućuju na to da su nakon gradnje samostanskih krila bili svođeni tek neki hodnici, dok je većina prostorija nadsvođena tek u 18. stoljeću. ${ }^{19}$ Gradnja svodova u refektorijima također nije jasno određena. Benger, primjerice, navodi da je 1734 . iznad zimskog refektorija izveden krov, ali s obzirom na to da se refektorij nalazi u prizemlju, vjerojatno je riječ o svodu. ${ }^{20}$ Iako je riječ o dvije najveće, ujedno i najvažnije samostanske prostorije, ljetni i zimski refektorij, po

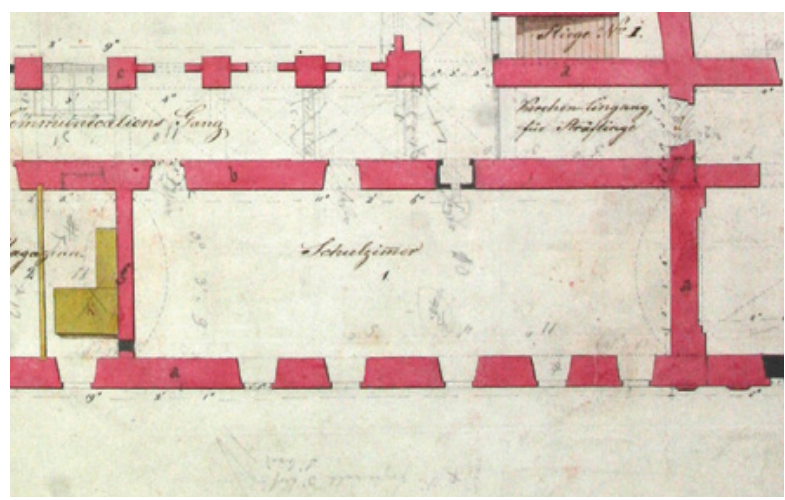

3. Detalj nacrta Franza Struppija iz 1851. s prikazom nekadašnjeg ljetnog refektorija. Crnom bojom naznačene su planirane adaptacije (planoteka Uprave za zaštitu kulturne baštine) Detail of the Lepoglava monastery plan from 1851, by Franz Struppi, showing the former summer refectory. Black marks the planned interventions (Ministry of Culture, Directorate for the Protection of Cultural Heritage)

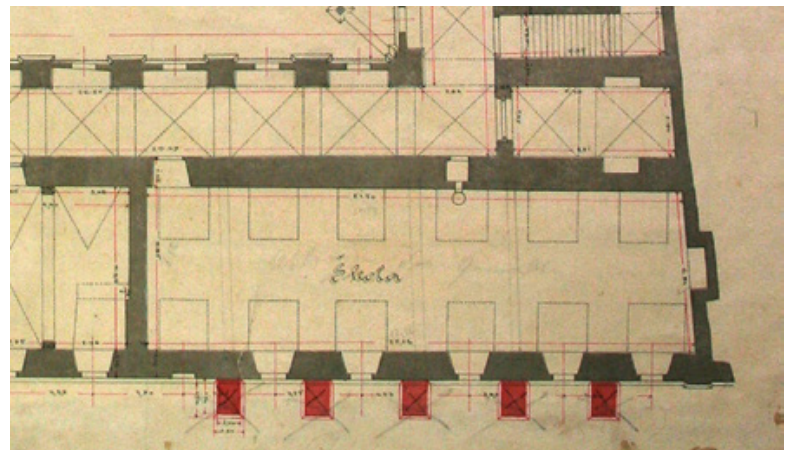

5. Detalj nacrta Žige Baločanskog iz 1880. s prikazom nekadašnjeg ljetnog refektorija. Vidljivo je planirano podupiranje vanjskog zida koje nije izvedeno (planoteka Uprave za zaštitu kulturne baštine) Detail of the Lepoglava monastery plan from 1880 by Žiga Baločanski. Former summer refectory with the proposed buttressing of the outer wall which was never executed (Ministry of Culture, Directorate for the Protection of Cultural Heritage)

svemu sudeći, nisu u početku bili svođeni. Držimo da je svod $u$ ljetnom refektoriju podignut $u$ vrijeme izvedbe štukatura, odnosno 1722. godine, osobito s obzirom na zapis iz 1733. koji navodi izvedbu novih slika na svodu i lukovima pa je izgledno da svod tada već postoji. Nadalje, svod je bio bačvasto oblikovan, ali s vrlo niskim i kratkim, pravokutno zaključenim susvodnicama, što ukazuje na to da se pri njegovoj gradnji predvidjelo i ukrašavanje središnjeg dijela, za što je bila potrebna veća slobodna površina. Čini se, dakle, da je svod izveden zajedno sa štukaturom i oslikanim medaljonima s prikazima sv. Pavla, a da su 1733. obnovljene ili izvedene neke nove slike na svodu.

Marija Mirković utvrđuje nastanak zidnih slika u refektoriju u više navrata. Kao najraniji ostavlja mogućnost početka 18. stoljeća kad u samostanu djeluje slikar laik Luka Markgraf. Smatra da je do izvedbe novih slika došlo istovremeno s gradnjom svoda 1722. godine, a pri- 


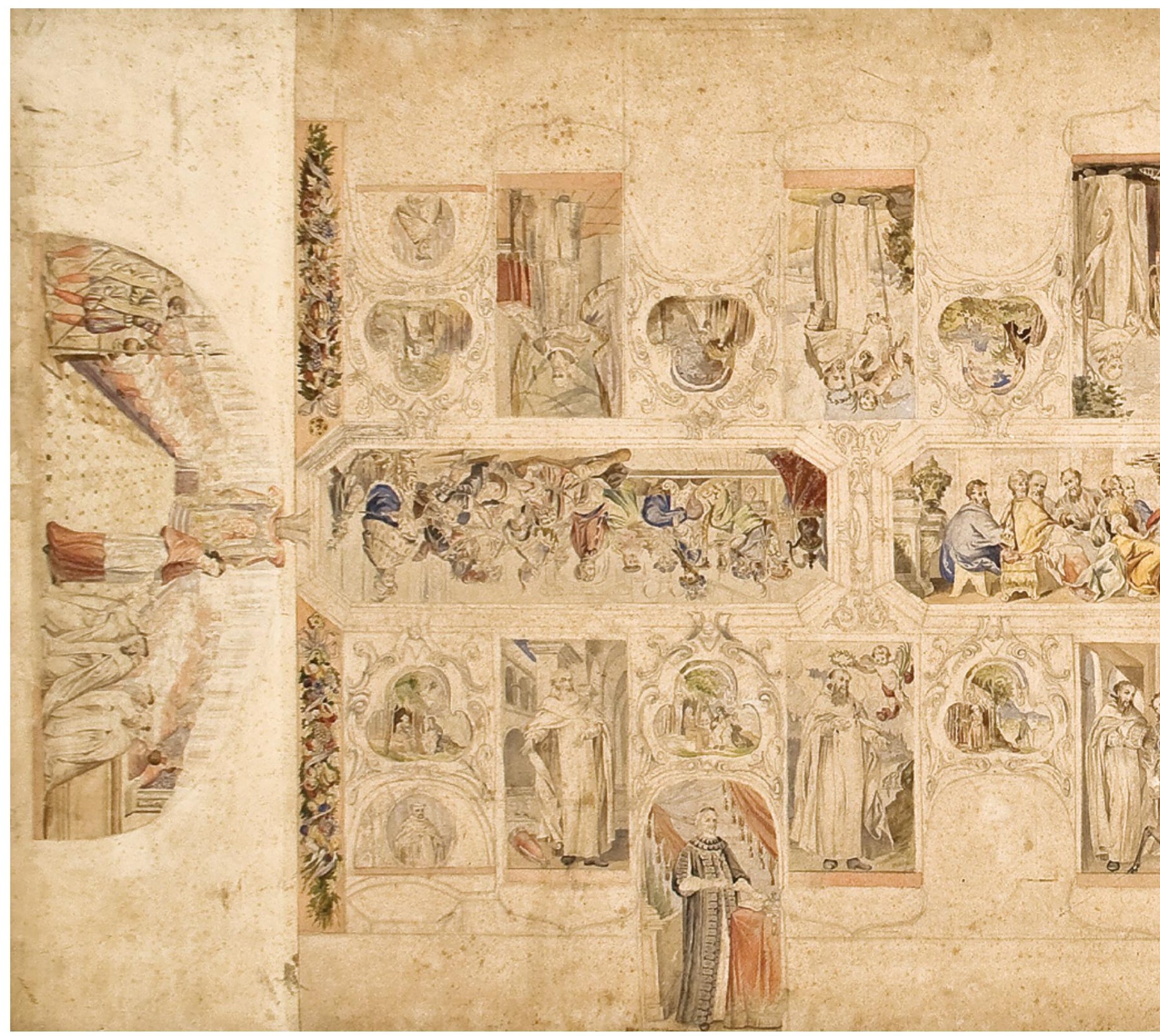

6. Akvarel Ferdinanda Quiquereza s prikazom dekorativne obrade zidova i svoda u nekadašnjem ljetnom refektoriju, 1878. (Hrvatski povijesni muzej)

Aquarelle drawing by Ferdinand Quiquerez depicting the decorative design of the walls and the vault in the former summer refectory in Lepoglava, 1878 (Croatian Museum of History)

pisuje ih Franji Bobiću. Godina 1733. svakako je vrijeme veće obnove, prilikom čega Ivan Ranger oslikava središnja velika polja svoda te intervenira na postojećem osliku. ${ }^{21}$

\section{Refektorij nakon prenamjene samostana u kaznionicu}

Ukinućem pavlinskog reda 1786., zgrade pavlinskog samostana prenamijenjene su za potrebe Čazmanskog kaptola koji je ondje imao sjedište sljedećih nekoliko desetljeća. Samostanske zgrade s vremenom se zapuštaju. Godine 1852. sklopljen je ugovor između Kaptola i države kojim se samostan iznajmljuje državi „na vječna vremena“, ${ }^{22}$ temeljem čega je bivši samostanski kompleks prenamijenjen u državnu kaznionicu. Zemaljska građevna uprava dala je izraditi arhitektonske nacrte postojećeg stanja samostana, u koje su ucrtani planirani zahvati za kaznionicu. Sačuvane su tri serije nacrta: jedna nepotpisana iz oko 1850 ., druga inženjera Franza Struppija iz 1851. i treća inženjera Johanna Polivke iz 1852., prema kojima je izveden veći dio zahvata. ${ }^{23}$ No nisu izvedeni svi zahvati prikazani na nacrtima, a neki koji su izvedeni - nisu ucrtani, pa nije moguće sa sigurnošću utvrditi baš svaku intervenciju. U svakom slučaju, postojeće su snimke korištene za ucrtavanje promjena i nekoliko desetljeća poslije.

Na trima tlocrtima prizemlja prikazan je i ljetni refektorij, a zanimljivo je vidjeti namjenu prostorije $u$ to doba. $\mathrm{Na}$ nacrtu iz oko $185^{\circ}$. vidi se prekrižen prvotni natpis 


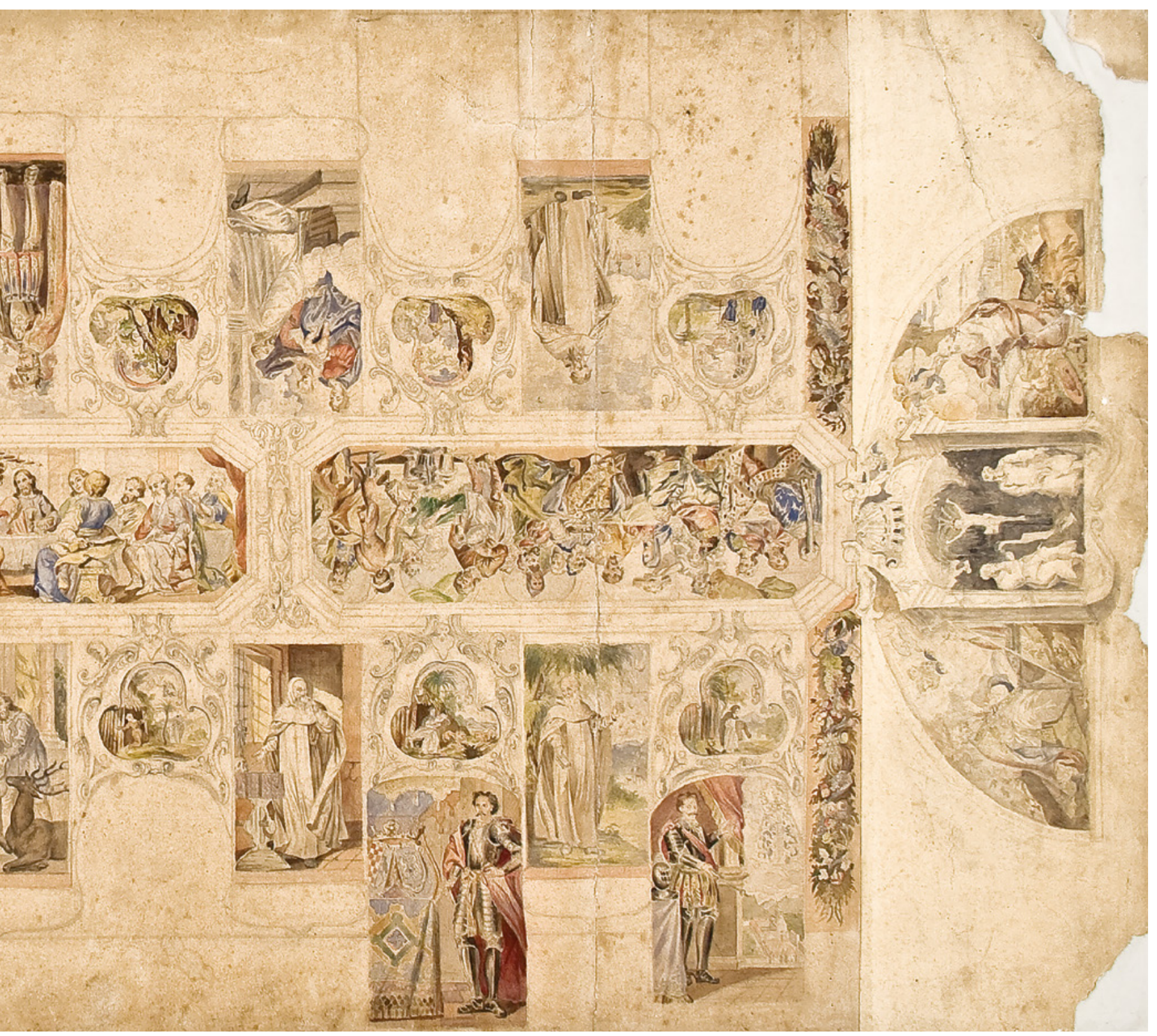

Schule und Refectorium für Sträftlinge, i napisana nova funkcija Spital (sl. 2). Na istom nacrtu vidljivo je zazidavanje i odzidavanje nekih otvora. Na Struppijevu nacrtu iz 1851. prostorija se naziva Schulzimmer i postoje dva ulaza, jedan na mjestu današnjeg, a drugi ispod zazidanog prozora prema hodniku, dok je drugi prozor prema hodniku pretvoren $\mathrm{u}$ znatno manji otvor (sl. 3). Na oba nacrta je već zazidan krajnji desni prozor na zapadnom zidu. Na Polivkinu nacrtu iz 1852 . vidi se da je prostorija pregrađena tankim zidom na dva dijela, pa je u manjem sjevernom dijelu upisano Besprechungszimmer, a u većem južnom Schulzimmer für Sträflinge (sl. 4). Nacrt prikazuje zazidavanje krajnjeg desnog prozora na zapadnom zidu te istovremeno postojanje oba prozora prema hodniku, ali i planirano razidavanje dijelova tog zida, vjerojatno radi reguliranja dimovodnih kanala.

$\mathrm{Na}$ nacrtima je važno primijetiti i način na koji je ucrtan svod refektorija. Na onom iz oko 1850 . te na Struppijevu, vide se samo segmentne linije duž kraćih strana prostorije koje sugeriraju bačvasti svod. Na Polivkinu se nacrtu linije ne vide, ali su zato ucrtane susvodnice, $i$ to kvadratnog oblika. Te će susvodnice biti ponovljene i na nacrtu iz 1880. godine (sl. 5). Riječ je o susvodnicama čiji vrhovi nisu uobičajeno šiljasti ili trokutasti, nego ravni ili vrlo blago segmentni, pa na tlocrtu susvodnica izgleda kao pravokutnik ili kvadrat. Kao primjer navedimo da 


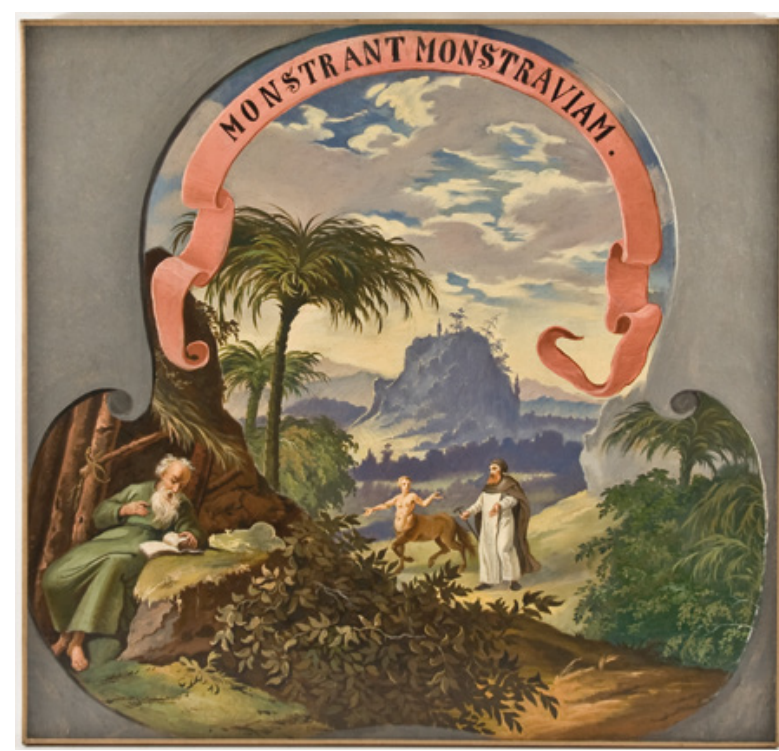

7. Akvarel Ferdinanda Quiquereza s prikazom trolisnog medaljona na svodu refektorija, 1878. (Hrvatski povijesni muzej) Aquarelle drawing of a trefoil medallion on the refectory vault, by Ferdinand Quiquerez 1878 (Croatian Museum of History)

se takve susvodnice nalaze i u refektoriju franjevačkog samostana u Krapini, pa vjerojatno nisu bile rijetkost. ${ }^{24}$ Na Polivkinu je nacrtu važan još jedan detalj, a to su tri izdužene pravokutne forme, blago zaobljenih kutova, duž središnjeg dijela prostorije. Po svemu sudeći, njima su označena tri medaljona duž vrha svoda koja su bila uokvirena štuko dekoracijom.

\section{Prva stručna valorizacija, dokumentiranje i pokušaji zaštite}

Unatoč političkim okolnostima koje su dovele do prenamjene samostana $\mathrm{u}$ kaznionicu, a time i neadekvatnog korištenja prostorije nekadašnjeg refektorija, sredinom 19. stoljeća uočavamo i prva nastojanja za njegovim očuvanjem. Svijest o vrijednostima umjetničke baštine Lepoglave ponajprije je došla od stručne javnosti. Ivan Kukuljević Sakcinski, konzervator i član Središnjeg povjerenstva za očuvanje i održavanje starih građevina za Hrvatsku i Slavoniju (1855. - 1869.), ${ }^{25}$ opisuje lepoglavski kompleks i njegove umjetnine te donosi svojevrsnu valorizaciju, što njegov rad ujedno čini i najranijim poznatim dokumentiranjem lepoglavskog sklopa. Kukuljević kaže da su zidne slike sačuvane $u$ četiri prostorije samostana, a za ljetni refektorij da su u sredini svoda tri velike slike s prikazom triju svadbi, dok su na zidovima i svodovima portretirani uvaženi pavlini i samostanski dobročinitelji, koje potom nabraja. ${ }^{26}$

Najpotpuniji opis ljetnog refektorija prije uništenja sastavit će 1878 . Izidor Kršnjavi, koji je u to vrijeme bio profesor povijesti umjetnosti i arheologije na zagrebačkom Sveučilištu. Ravnateljstvo kaznionice je 27. listopada 1878. godine uputilo molbu Vladinu Odjelu za pravo- suđe $u$ kojoj je izažena zabrinutost zbog stanja fresaka $u$ nekadašnjem samostanu, jer su oslikane prostorije služile kao radionice. ${ }^{27}$ Zemaljska vlada poslala je Kršnjavoga da pregleda sačuvane zidne slike te predloži daljnje intervencije. U Izvješću, poslije objavljenom kao članak u Viencu, Kršnjavi navodi da slike postoje samo u četiri prostorije te da su okružene štuko ukrasima. Daje opis svoda nekadašnjeg ljetnog refektorija: „Strop ote dvorane je tako razredjen, da u badnjasti svod sa oba duga zida po strani svod izravno prislanja oblukom. Sam svod razdieljen je štukaturom $u$ troje. $U$ tih, 6 metara dugih a 2 metra širokih zakrivljenih površinah naslikane su tri velike slike na ljepu.“28

Nadalje, detaljno opisuje trolisne medaljone unutar susvodnica na kojima su bile prikazane scene iz života svetih pustinjaka Pavla i Antuna. ${ }^{29}$ Kršnjavi ukratko opisuje svaki medaljon posebno, navodi njegove dimenzije, prepoznaje ikonografski prikaz i daje kritičko mišljenje o umjetničkoj vrijednosti ili stanju slike. Na dijelu svoda između susvodnica Kršnjavi je vidio niz portreta znamenitih pavlina, među kojima ističe portret Martina Borkovića. Opisuje i dvije slike na kraćim stranicama refektorija te nišu s raspelom i dvojicom svetih pustinjaka.

Uz šturi opis rasporeda i teme prikaza fresaka na zidovima i svodu ljetnog refektorija, izvještaj Izidora Kršnjavog je važan i zbog njegova kritičkog osvrta na umjetničku vrijednost fresaka. ${ }^{30}$ Suprotno od Kukuljevića, Kršnjavi smatra da je srednja od triju svodnih scena najlošije izrađena, dok bočnima priznaje određenu umjetničku vrijednost. Nadalje, portrete pavlina $u$ donjem dijelu svoda ocjenjuje kao manje kvalitetan rad („pogriešeni u proporcijah i loši u nacrtu“). ${ }^{31}$ Kao kvalitetnije dijelove oslika refektorija ističe likove svetaca na južnom zidu, posebice lik sv. Augustina. ${ }^{32}$ Svodnu štukaturu, koja je okruživala zidne slike, Kršnjavi ne ocjenjuje kao posebno lijepu i ističe da je štuko dekoracija nekada bila pozlaćena, no da je naknadno prekrivena debelim bijelim naličem pa su oblici izgubili oštrinu. Jednako tako, debelim su slojem prekriveni i kipovi u niši na južnom zidu. Kršnjavi ipak zaključuje da je ljetni refektorij prostor visoke umjetničke i dekorativne vrijednosti, u kojima je većina fresaka kvalitetno izrađena. Kvaliteta cijele kompozicije kompenzira manju vrijednost pojedinih lošijih dijelova, pa je u konačnici, prema njegovu mišljenju, stvoren „veoma liep, bogat i harmoničan skup“ ${ }^{33}$ Njegova preporuka ravnateljstvu kaznionice bila je da se zidne slike ne skidaju i ne prenose u Zagreb, kako je bilo predloženo, nego da se preslikaju.

Kršnjavijev je prijedlog bio prihvaćen. Slijedom toga, u Lepoglavu je poslan slikar Ferdinand Quiquerez koji je izradio crtež cijelog svoda i četiri kopije pojedinih detalja (sl. 6, 7). ${ }^{34}$ Ti crteži, kao i Quiquerezova bilježnica sa skicama, danas se čuvaju u Hrvatskom povijesnom muzeju. Zahvaljujući crtežu svoda, koji je izrađen olovkom i akvareliran, s velikom preciznošću možemo rekonstrui- 
rati izgled svodne dekoracije. Crtež je prikazan kao razvijeni spljošteni plašt svoda i zidova. Čitanje Quiquerezova crteža otežava način slikanja odozdo prema gore jer dolazi do zrcalne zamjene istočne i zapadne strane prikaza po središnjoj osi. ${ }^{35} \mathrm{Na}$ akvarelu je osobito važan i prikaz štukature koja je tvorila bogat okvir oslikanim poljima, što je gotovo i jedini dokument o njezinu postojanju. ${ }^{36}$

Neposredno prije uništenja svoda, lepoglavski samostan je posjetio i arheolog Šime Ljubić. Većinu fresaka u samostanu ocijenio je kao djela „neznatne vrijednosti“, koja imaju više povijesnu nego umjetničku vrijednost, ali je zaključio da ih treba ostaviti in situ. Istaknuo je, doduše, da je svod u vrlo lošem stanju te da ga što prije treba poduprijeti kako se ne bi srušio. Predlaže da se prostorija koristi „jedino za najplemenitije svrhe, naime za knjižnicu, ljekarnu itd.“37

Nije poznato je li uprava kaznionice poduzela kakve akcije za podupiranje oštećenog svoda, ali je središnju Hrvatsku ubrzo pogodio razoran potres, koji je teško oštetio lepoglavski sklop, posebno nekadašnji ljetni refektorij.

\section{Rušenje svoda u potresu 1880 . godine}

Veliki zagrebački potres 9. studenoga 188o. godine uzrokovao je snažna oštećenja na starim strukturama lepoglavskog samostana. Popucali su glavni zidovi u smjeru sjever-jug, dok su se oni u smjeru istok-zapad izbočili $6-8 \mathrm{~cm}$, što je uzrokovalo napuknuće svodova..$^{38}$ Oštećeni svodovi i srednji zidovi, koji se u potresu nisu sami urušili, netom poslije su razgrađeni. Tada su stradali gotovo svi svodovi na prvom i drugom katu sjevernog krila te svodovi oba samostanska refektorija.

Odmah nakon detektiranja oštećenja, inžinir Žiga Baločanski iz Građevnog ureda Varaždinske županije izradio je nacrte za obnovu zgrade kaznionice oštećene u potresu (vidi sl. 5). ${ }^{39}$ Glavni dio obnove bio je na sjevernom krilu, gdje je na gornjim etažama došlo do promjene tlocrtne dispozicije. ${ }^{4^{\circ}}$ Zanimljivo je, međutim, obratiti pozornost na planirane zahvate na ljetnom refektoriju. Na prikazanom tlocrtu prostorije refektorija, koja je imenovana kao Škola, vidljivo je da je s vanjske strane perimetralnog zida refektorija, između prozora, planirana gradnja pet jakih upornjaka pravokutnog presjeka. Od toga se projekta očito odustalo te je u konačnici svod potpuno razgrađen. U prostoriji su ostale sačuvane tek zidne slike i grota na južnom zidu. ${ }^{41}$

Stanje refektorija nakon uklanjanja svoda, a prije Drugog svjetskog rata, poznato je s niza fotografija, rađenih $u$ sklopu popisivanja i fotografskog snimanja umjetničkih spomenika Jugoslavenske akademije znanosti i umjetnosti. ${ }^{42}$ Umjesto nekadašnjeg bačvastog svoda sa zidnim slikama i štukaturom, refektorij je bio natkriven ravnim stropom. Na istočnom zidu su još bili vidljivi portreti samostanskih dobrotvora te lunete na sjevernom i južnom zidu. Na južnom je također izvanredno dobro sačuvana

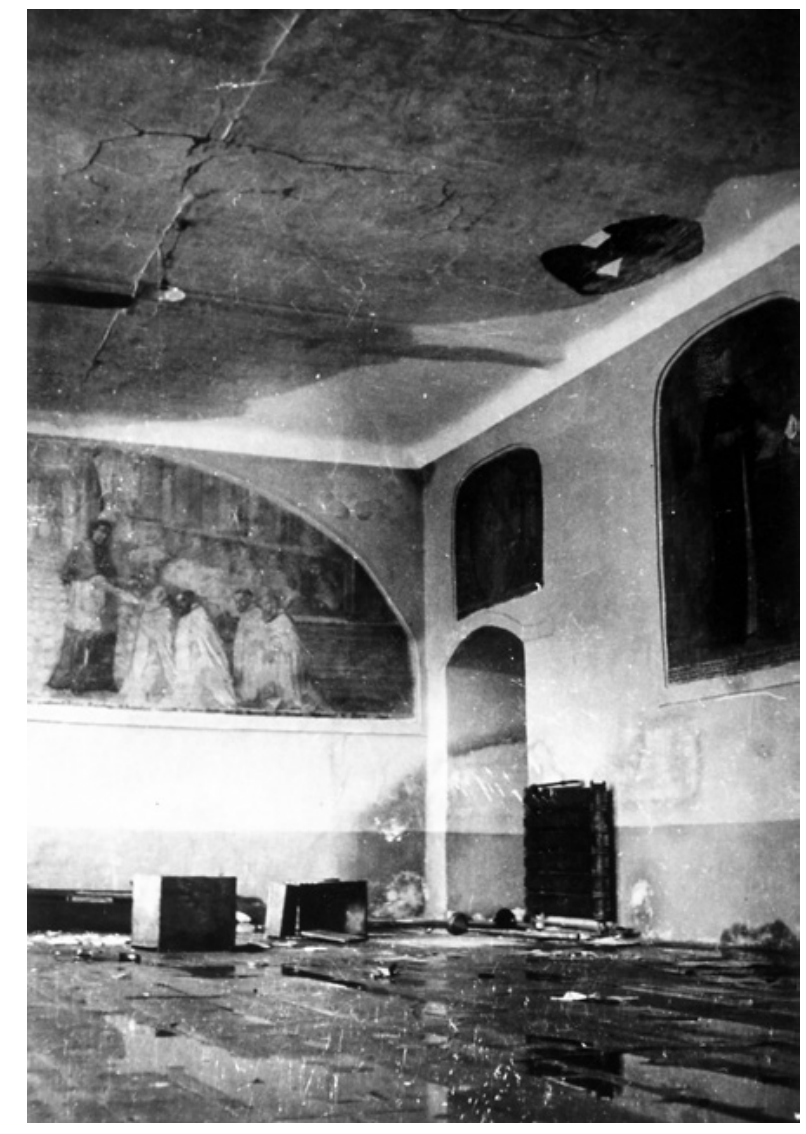

8. Pogled na sjeveroistočni dio refektorija prije rušenja stropa i gornjih etaža zapadnog krila (MK, fototeka Uprave za zaštitu kulturne baštine, snimio F. Ladika, 1944.)

Northeast view of the refectory before the demolition of the west wing's upper floors (Ministry of Culture, Directorate for the Protection of Cultural Heritage, photo by F. Ladika, 1944)

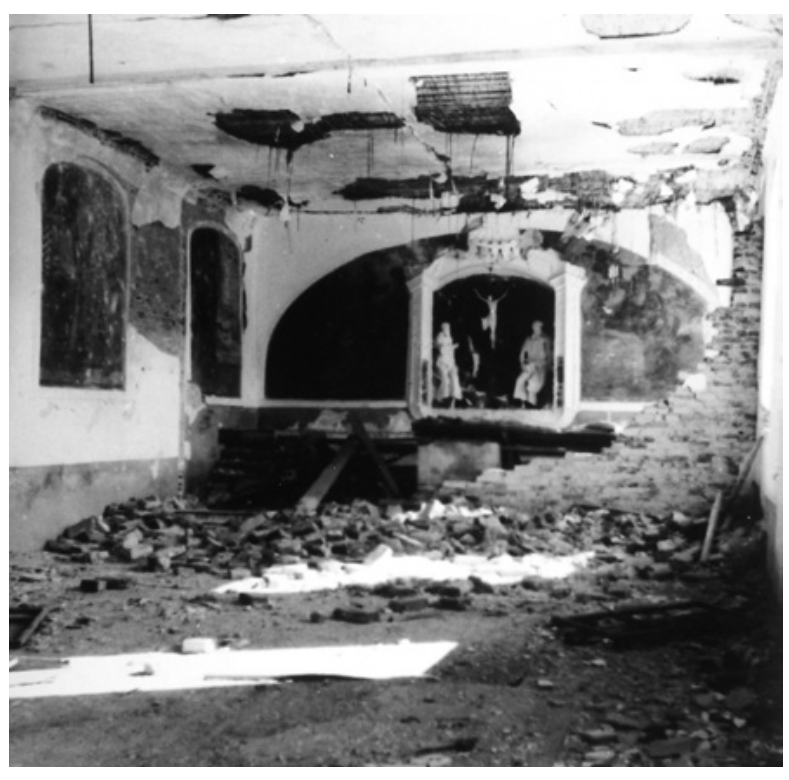

9. Pogled na jugoistočni dio ljetnog refektorija prije rušenja stropa i gornjih etaža zapadnog krila (fototeka Uprave za zaštitu kulturne baštine, snimio M. Davila, 1945.)

Southeast view of the refectory before the demolition of the west wing's upper floors (Ministry of Culture, Directorate for the Protection of

Cultural Heritage, photo by M. Davila, 1944) 


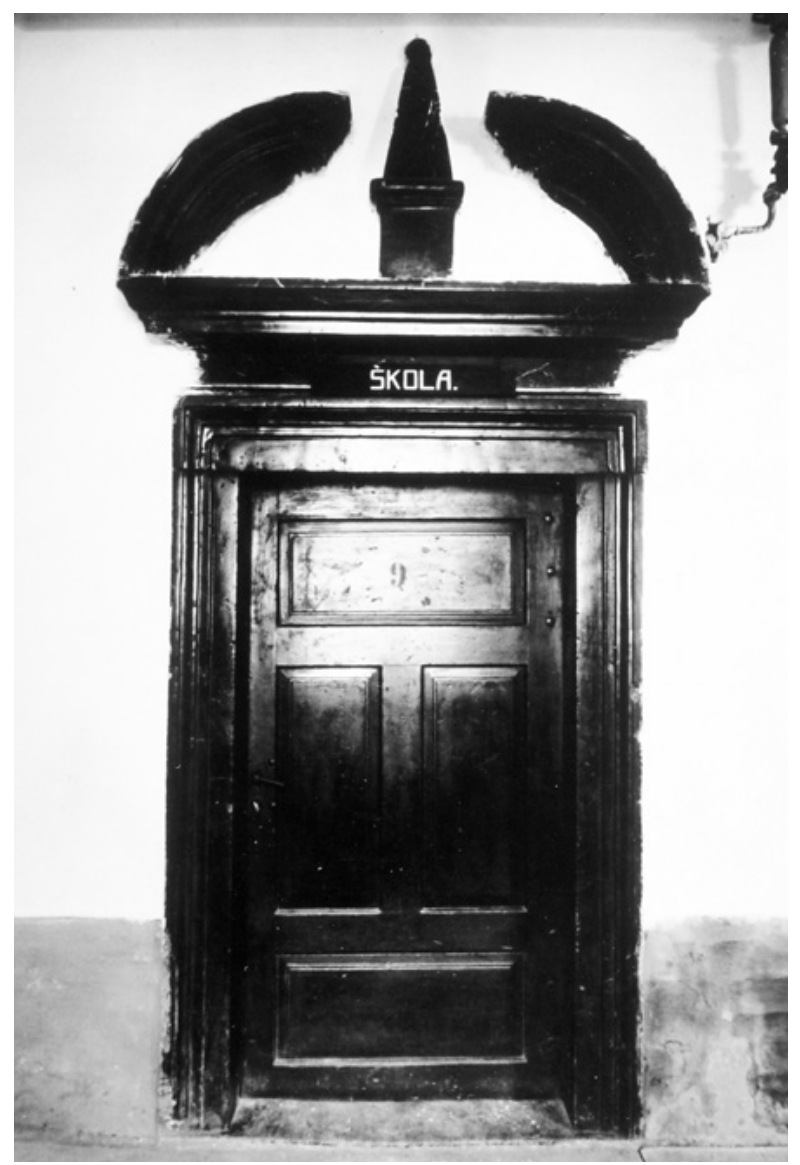

10. Kameni portal ulaza u ljetni refektorij, u hodniku zapadnog krila samostana (fototeka Uprave za zaštitu kulturne baštine, snimio $\bigoplus$. Griesbach, 1938.)

Stone portal of the refectory (Ministry of Culture, Directorate for the Protection of Cultural Heritage, photo by $Đ$. Griesbach, 1938)

grota s kipovima s bogatim štuko okvirom (sl. 20), a bio je sačuvan i portal ulaza u prostoriju s dekorativnim kamenim okvirima (sl. 10), koji je zabilježen i stotinjak godina prije na Polivkinu nacrtu.

\section{Stradavanje u Drugom svjetskom ratu}

Do idućeg većeg oštećenja kaznioničkih zgrada i samog ljetnog refektorija došlo je 1943. godine. Zapisi govore da su partizanski odredi napali kaznionicu uvečer 12. srpnja, a tijekom borbe razvio se požar u prizemlju istočnog krila. U požaru su stradale sakristija i pravoslavna kapela za zatvorenike koja se nalazila uz nju, a uništena je i zidna dekoracija zimskog refektorija. ${ }^{43}$

Neizravna posljedica borbe 1943. bila je razgradnja oštećenog krovišta nad zapadnim krilom samostana početkom 1944. godine, koje je ostalo nenatkriveno. U ožujku 1944. lepoglavsku kaznionicu posjetio je izaslanik Državnog konzervatorskog zavoda, slikar Ferdo Ladika, kako bi utvrdio stanje očuvanosti bivšeg samostanskog sklopa. ${ }^{44}$ Iz Ladikina izvještaja saznajemo da je prostorija nekadašnjeg ljetnog refektorija tada služila kao školska dvorana i dvorana za predstave, radi čega je njezin južni dio zidom

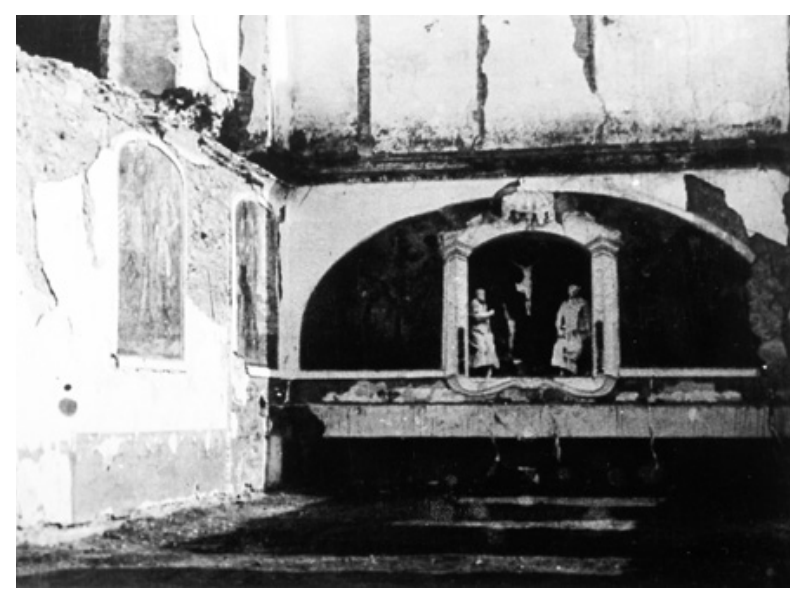

11. Pogled na južni dio refektorija nakon rušenja gornjih etaža zapadnog krila (fototeka Uprave za zaštitu kulturne baštine, snimio T. Stahuljak, 1946.)

South view of the refectory after demolition of the west wing's upper floors (Ministry of Culture, Directorate for the Protection of Cultural Heritage, photo by T. Stahuljak, 1946)

bio pregrađen za pozornicu. Dvorana je imala dva ulaza, s tim da je na izvornom ulazu (na sjeveroistočnom kraju dvorane), sa strane hodnika, još bio sačuvan dekorativni kameni okvir od crnoga granita. ${ }^{45}$

Ladika izvještava da je, unatoč postojanju dvaju katova iznad razine prizemlja, vlaga u ljetnom refektoriju prodrla do polovice visine zidnih struktura prizemlja te je prijetila slikama sačuvanima na zidovima. ${ }^{46}$ Daje detaljan opis svakog portreta s odgovarajućim natpisom, dimenzijama i stanjem u kojem se nalaze. ${ }^{47} \mathrm{Na}$ Ladikinim fotografijama može se uočiti da su zidne slike još u relativno dobrom stanju, s čitliivim natpisima ispod njih (sl. 8). U najlošijem stanju bila je slika Ivaniša Korvina, kojoj je gornja polovica teže oštećena. Na portretu Emerika Esterhazyja uočio je oštećenje od metaka. Ispod prizora južnog i sjevernog zida nestali su slikani vijenci s voćem. Opisuje i kipove u niši, za koje navodi da su rađeni od gipsa kaširanom kudjeljom. Između dva portreta, otprilike na sredini istočnog zida, Ladika je pretpostavio da bi se moglo nalaziti još oslika, međutim, danas je poznato da su na tom mjestu bila dva prozorska otvora prema samostanskom hodniku. Zbog nezaštićenosti oslika, Ladika je u izvještaju predložio da se preostale zidne slike skinu i pohrane na sigurno mjesto, prije nego što potpuno nestanu. ${ }^{48}$

U svibnju 1945. godine, pri povlačenju njemačkih trupa, došlo je do velike eksplozije streljiva u blizini zapadnog samostanskog krila, koje je teško oštećeno (sl. 11). Blok s knjižnicom, dograđen 1711. godine ispred lađe crkve, $u$ eksploziji je također oštećen pa se zapadno pročelje crkve nagnulo naprijed, što je uzrokovalo pucanje zida i urušavanje crkvenog zabata. Zidne strukture gornjih dviju etaža zapadnoga krila samostana bile su toliko oštećene da su se morale potpuno ukloniti. ${ }^{49}$ Djelatnici Konzervatorskog zavoda fotografirali su stanje lepoglavskog sa- 


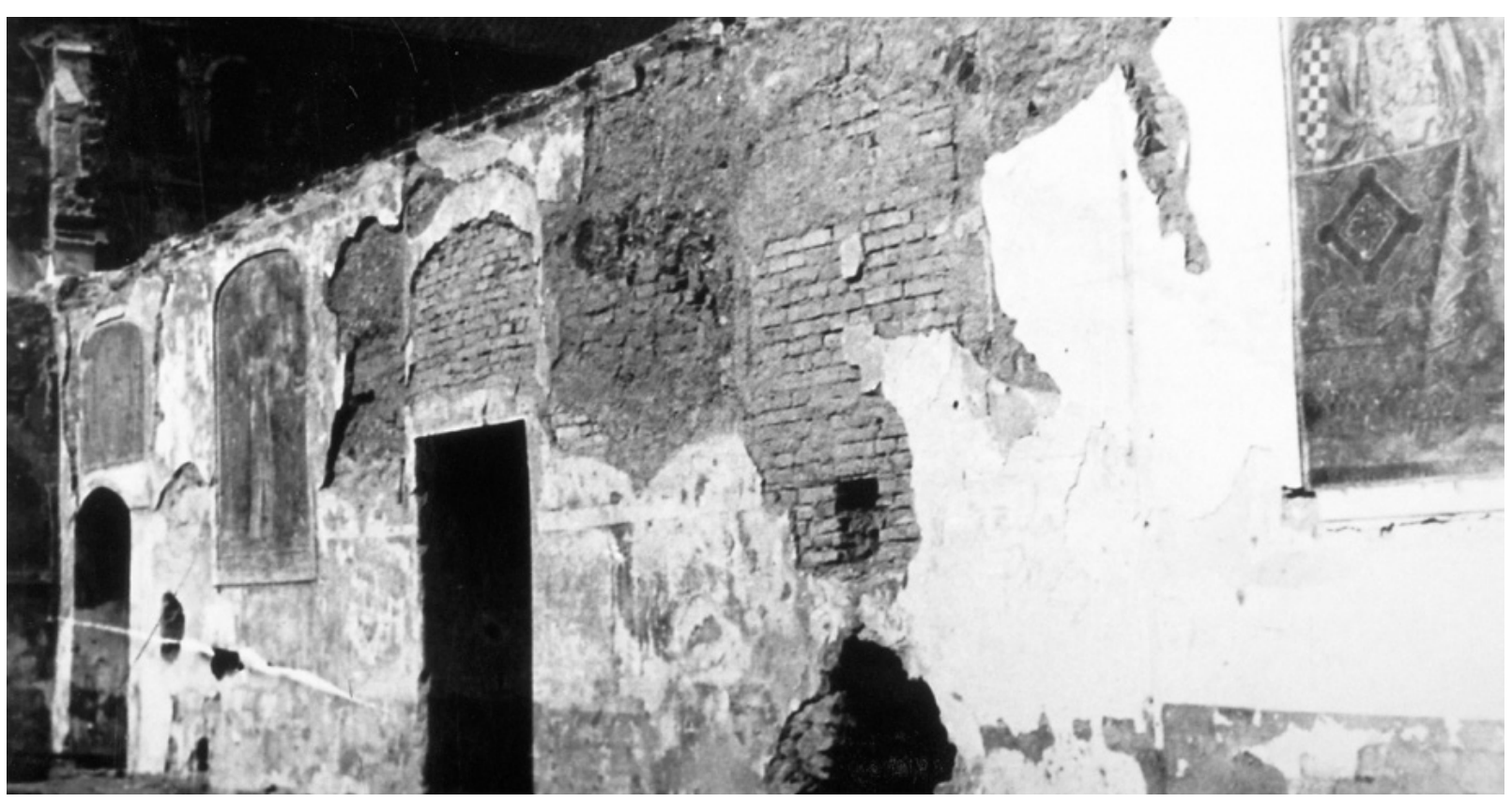

12. Istočni zid refektorija nakon rušenja gornjih etaža zapadnog krila (fototeka Uprave za zaštitu kulturne baštine, snimio T. Stahuljak, 1946.)

East wall of the refectory after demolition of the west wing's upper floors (Ministry of Culture, Directorate for the Protection of Cultural Heritage, photo by T. Stahuljak, 1946)

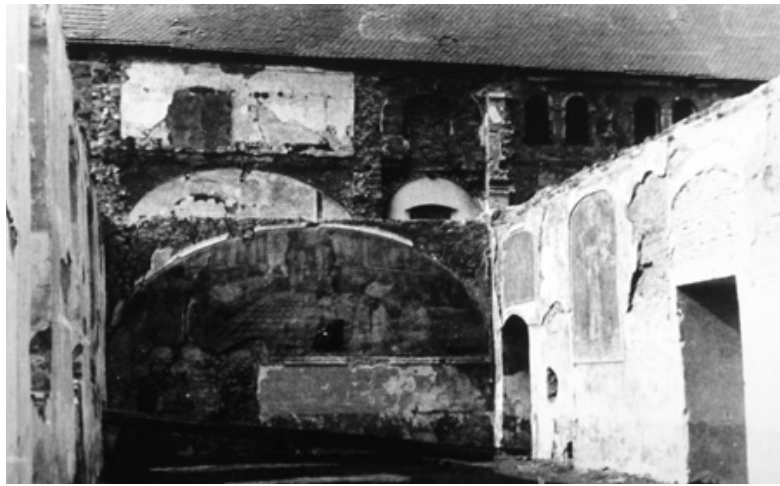

13. Pogled na sjeveroistočni dio refektorija nakon rušenja gornjih etaža zapadnog krila (fototeka Uprave za zaštitu kulturne baštine, snimio T. Stahuljak, 1946.)

Northeast view of the refectory after demolition of the west wing's upper floors (Ministry of Culture, Directorate for the Protection of Cultural Heritage, photo by T. Stahuljak, 1946)

mostana prije i tijekom razgradnje pa je moguće utvrditi razmjere oštećenja. Zbog jačine eksplozije, na pročelju su $\mathrm{u}$ zoni prizemlja ispali kameni prozorski okviri, dok je $\mathrm{u}$ unutrašnjosti refektorija srušen poprečni zid ispred pozornice i dijelovi stropa (sl. 9). Sa zidova refektorija mjestimice je otpao žbukani sloj, no većina fresaka je još bila čitava. Veća oštećenja žbukanog i slikanog sloja vidljiva su na zapadnim krajevima sjevernog i južnog zida prostorije.

U proljeće 1946. godine kaznionica je počela s rušenjem oštećenih zidnih struktura gornjih katova (sl. 11). Zidovi zapadnog krila samostana razgrađeni su do razine prizemlja, a uklonjene su i međukatne konstrukcije,

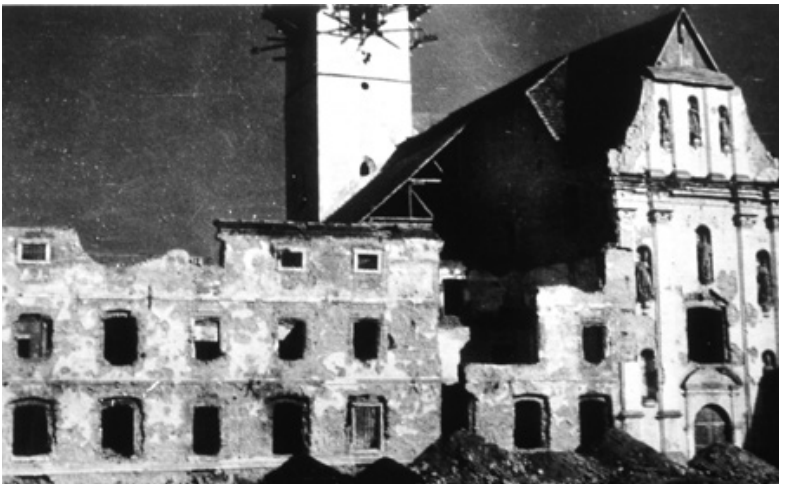

14. Pogled na zapadno krilo samostana i pročelje crkve nakon eksplozije i početak razgradnje gornjih etaža (fototeka Uprave za zaštitu kulturne baštine, snimio T. Stahuljak, 1946.)

Monastery's west wing damaged by the explosion and the beginning of the demolition of the upper floors (Ministry of Culture, Directorate for the Protection of Cultural Heritage, photo by T. Stahuljak, 1946)

tako da su zidovi s oslicima ostali pod otvorenim nebom, potpuno izloženi vremenskim uvjetima $(\mathbf{s l} .12,13,14) .^{50}$ Konzervatorski zavod u Zagrebu, koji je istovremeno radio na statičkoj sanaciji crkve, ${ }^{51}$ inzistirao je na sudjelovanju u obnovi samostana, ali je suradnja s upravom kaznionice bila znatno otežana. Zavod je Ministarstvu unutarnjih poslova, koje je upravljalo kaznionicom, poslao dopis u kojemu je iznio dva prijedloga rekonstrukcije zapadnog krila. Prvi je podrazumijevao rekonstrukciju starog pročelja, prema poznatim nacrtima, ali sa suvremeno projektiranom unutrašnjošću, prilagođenom potrebama kaznionice, dok je drugi pristup dopuštao gradnju posve suvreme- 


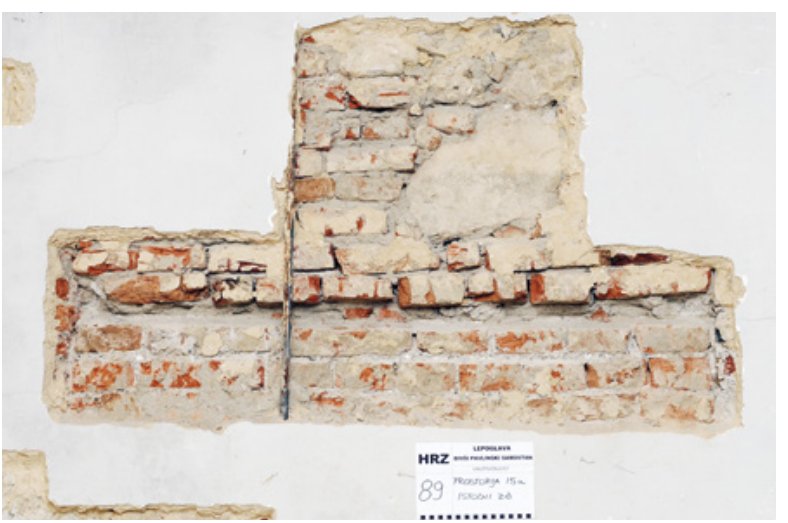

15. Sonda s vidljivim tragovima pete svoda: nizovi opeke slagani ukoso prema gore (donja strana sonde), prekid u kontinuitetu građe te rahla mješovita građa gornjeg dijela koja predstavlja popravak nakon izbijanja dijelova svodne konstrukcije iz zida (fototeka HRZ-a, snimio J. Škudar, 2014.)

Probe showing the traces of the removed vault: rows of bricks inclined facing upwards (lower part), discontinuation of the masonry, and the weak masonry of the upper part built in as a repair after the removal of the vault (Croatian Conservation Institute Photo Archive, photo by J. Škudar, 2015)

nog krila, ali koje bi volumenom, omjerom i bojom bilo usklađeno s ostatkom kompleksa. Jedini postavljeni uvjet bilo je čuvanje zidova nekadašnjeg refektorija sa zidnim slikama i kamenog okvira portala refektorija, koji je tada još postojao. ${ }^{52}$ Uprava kaznionice je, međutim, odlučila iznova sagraditi zapadno krilo s novim oblikovanjem, i to bez dogovora s konzervatorima. U prizemlju je sačuvan izvorni tlocrtni raspored s prostorijama koje se nižu uz hodnik, dok je u gornjim etažama formirana velika dvoetažna polivalentna dvorana. Iako je krilo volumenom i visinom ponavljalo prijašnju situaciju, na vanjskom, zapadnom pročelju poništeni su otvori gornjih etaža, a na

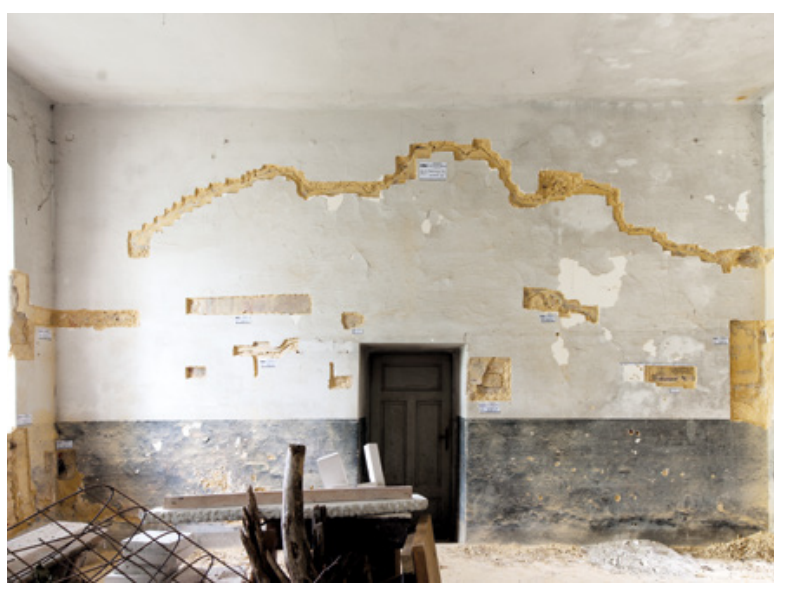

17. Sondiranje ostataka zidnog oslika na sjevernom zidu ljetnog refektorija, kojim je ustanovljen gornji rub oslikane površine (HRZ, snimio J. Škudar, 2014.)

Probing of the remains of the wall painting on the refectory's north wall, the discovered edge of the preserved painted surface (Croatian Conservation Institute Photo Archive, photo by J. Škudar, 2014)

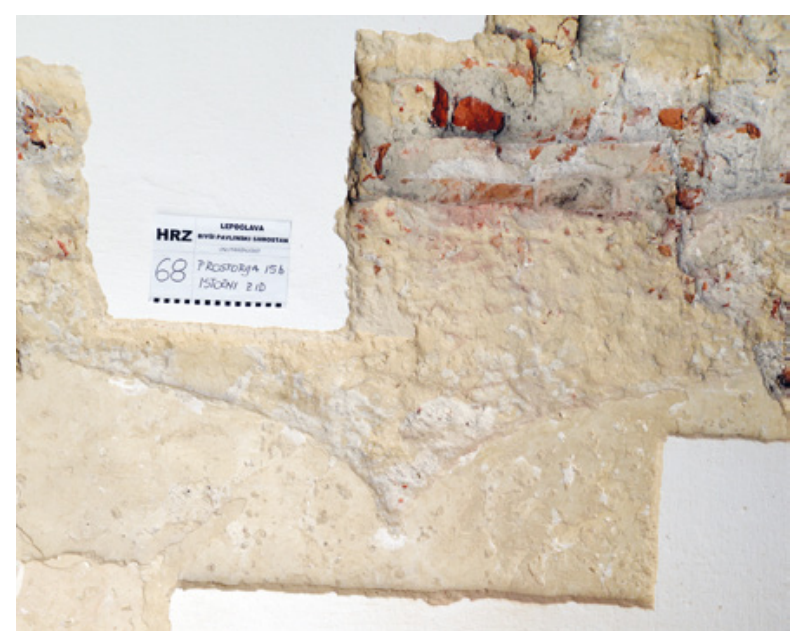

16. Sonda koja prikazuje trag žbukanog ornamenta V-oblika ispod nekadašnje pete svoda na istočnom zidu (fototeka HRZ-a, snimio J. Škudar, 2014.)

Probe showing the traces of a V-shaped plastered ornament below the springer of the vault (Croatian Conservation Institute Photo Archive, photo by J. Škudar, 2015)

istočnom su, $\mathrm{u}$ rasteru nekadašnjih prozorskih osi, formirani uski, dugački parovi prozora.

Radovi su vjerojatno provedeni 1947. godine, kad konzervatori Ljubo Karaman i Mladen Fučić te restaurator Zvonimir Wyroubal putuju u Lepoglavu s namjerom pregleda fresaka ljetnog refektorija, kako bi se odlučilo o njihovu preseljenju u Zagreb, za što su bila osigurana sredstva. Međutim, nakon dolaska u Lepoglavu, rečeno im je da je uprava kaznionice već obavila radove natkrivanja prostorije, te da su tijekom tih radova zidne slike u nekadašnjem refektoriju uništene. Konzervatori su zahtijevali da pregledaju šutu kako bi eventualno pronašli pojedine ulomke žbuke s oslikom, no nije im bio dopušten ulazak $u$ kaznionicu. ${ }^{53}$

Iako nije moguće točno utvrditi opseg tada izvedenih radova, može se pretpostaviti da su prilikom uređenja unutrašnjosti ostaci fresaka u refektoriju prežbukani. Zazidana je niša na južnom zidu, kako je to zabilježeno na jednom kipu unutar niše (Zazidano 30. IV. 1947.), a zasigurno je tada prostorija zidom podijeljena na dva dijela te je $\mathrm{u}$ obje izliven betonski pod, postavljena nova stolarija i rešetke na prozorima.

\section{Konzervatorsko-restauratorski istraživački radovi 2014. godine}

Pedesetak godina refektorij je, podijeljen na dvije prostorije, služio kao pomoćna prostorija kaznionice. Kraj 20. stoljeća dočekao je zapušten, vlažan i mračan te tamno oličenih zidova. Novo poglavlje u njegovoj povijesti, a općenito i povijesti cijele Lepoglave, počet će 1999. vraćanjem bivšeg samostana Crkvi. Novoosnovana Varaždinska biskupija, u čijoj se ovlasti našao bivši samostan, 


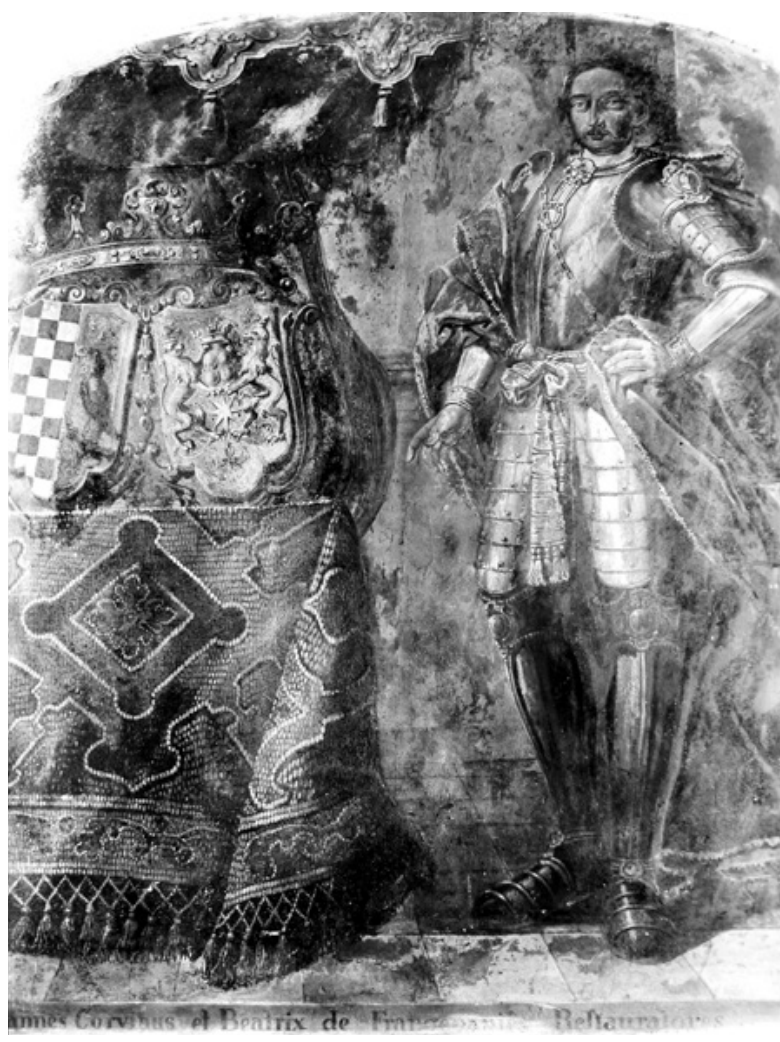

18. Medaljon s prikazom Ivaniša Korvina na istočnom zidu snimljen 1938. godine (fototeka Uprave za zaštitu kulturne baštine, snimio Đ. Griesbach, 1938.)

Medallin portraying Ivaniš Korvin on the east wall in 1938 (Ministry of Culture, Directorate for the Protection of Cultural Heritage, photo by Đ. Griesbach, 1938)

inicirala je veliku obnovu kako bi se u samostan smjestio pastoralni centar.

Prva faza obnove trajala je od 2003. do 2010. godine. Obuhvatila je sjeverno krilo te sjeverni dio istočnog krila samostana. Obnova je započeta konzervatorskim istraživanjima Hrvatskog restauratorskog zavoda 2003./2004. godine, ${ }^{54}$ a vođenje radova nastavio je Konzervatorski odjel u Varaždinu. Istraživanja su tada obuhvatila sondiranje samo sjevernog i dijela istočnog krila samostana, no otvoreno je nekoliko sondi u zapadnom krilu, i to $u$ dvjema prostorijama koje su nekad činile ljetni refektorij. Tih nekoliko sondi pokazalo je da su na istočnom zidu još sačuvani tragovi oslika, što znači da oslik nije bio uništen, kako se do tada držalo, već samo prežbukan. Također, napravljena je manja građevinska sonda kojom je pronađena i zazidana niša na južnom zidu, a kroz nju su se mogli vidjeti i dijelovi štuko kipova. No budući da je prva faza obnove bila prije svega usmjerena na sjeverno krilo, projektiranjem i radovima koji su uslijedili željelo se primarno rekonstruirati sjeverno krilo, a zapadno krilo ostalo je netaknuto sve do 2014. godine. Varaždinska je biskupija tada inicirala drugu fazu obnove samostana te je angažirala Hrvatski restauratorski zavod za istraživačke radove u zapadnom, istočnom i južnom krilu. ${ }^{55}$

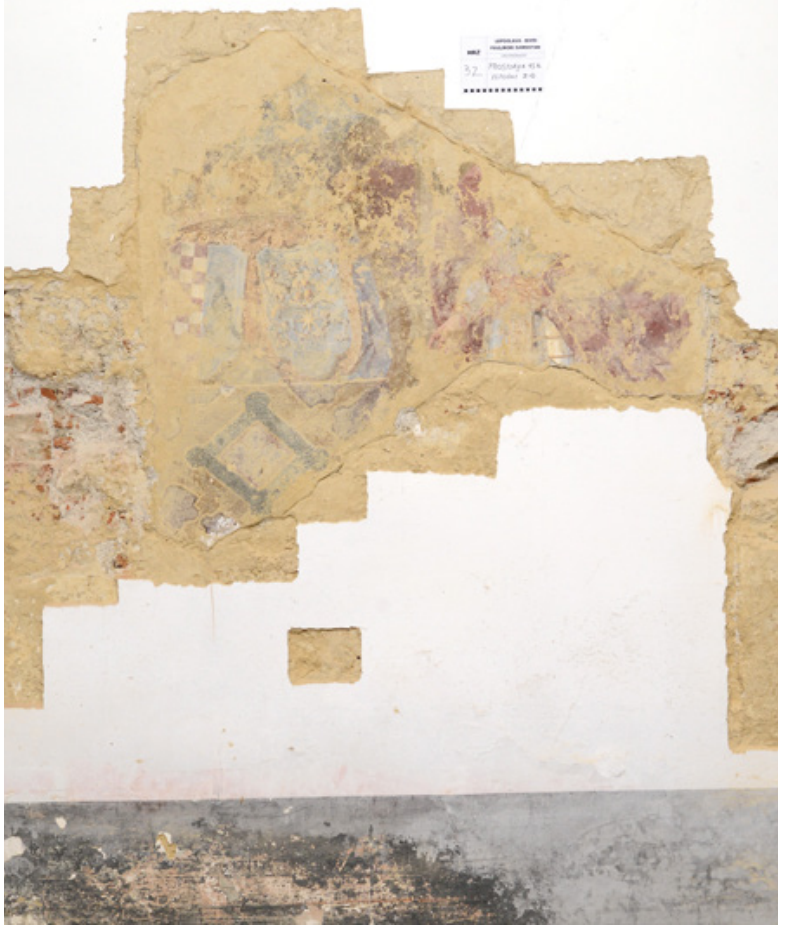

19. Sonda koja prikazuje ostatak medaljona s likom Ivaniša Korvina tijekom istraživanja 2014. (fototeka HRZ-a, snimio J. Škudar, 2014.) Probe showing the ramins of Ivaniš Korvin's medallion during research in 2014 (Croatian Conservation Institute Photo Archive, photo by J. Škudar, 2014)

Provedena su detaljna istraživanja ljetnog refektorija da bi se utvrdilo opće stanje i očuvanost prostorije, format $i$ položaji zidova i otvora, tragovi svođenja te dekorativne opreme. Istraživanja su rezultirala mnogim novim spoznajama o refektoriju, a ovdje donosimo tumačenje svih važnih nalaza do kojih smo tada došli.

Prostorija je, dakle, podijeljena pregradnim opečnim zidom na dvije, sjevernu i južnu, koje su povezane vratima. Sondiranje je potvrdilo očitu pretpostavku da je zid podignut naknadno, tako da ćemo $u$ nastavku obje prostorije razmatrati kao jednu, radi lakšeg snalaženja.

Danas postoje dva ulaza u prostoriju. Na sjevernom zidu su vrata koja vode prema susjednoj prostoriji, ali su ona probijena naknadno jer je, kao što ćemo vidjeti, njihovim probijanjem uništen i dio zidne slike na tom zidu. Glavni, ujedno i jedini izvorni ulaz u refektorij bio je, dakle, iz hodnika, a hodnik se nalazi na krajnjoj lijevoj strani istočnog zida. Niša vrata glavnog ulaza je s unutarnje strane naknadno proširena izvedbom izrazito ukošene desne špalete. S vanjske je taj ulaz imao reprezentativno oblikovan kameni portal, poznat s jedne povijesne fotografije (vidi sl. 10) i Polivkina nacrta iz 1852. godine. Portal je imao profilirane dovratnike i bio nadvišen prekinutom nadstrešnicom između čijih se odsječaka uzdi- 


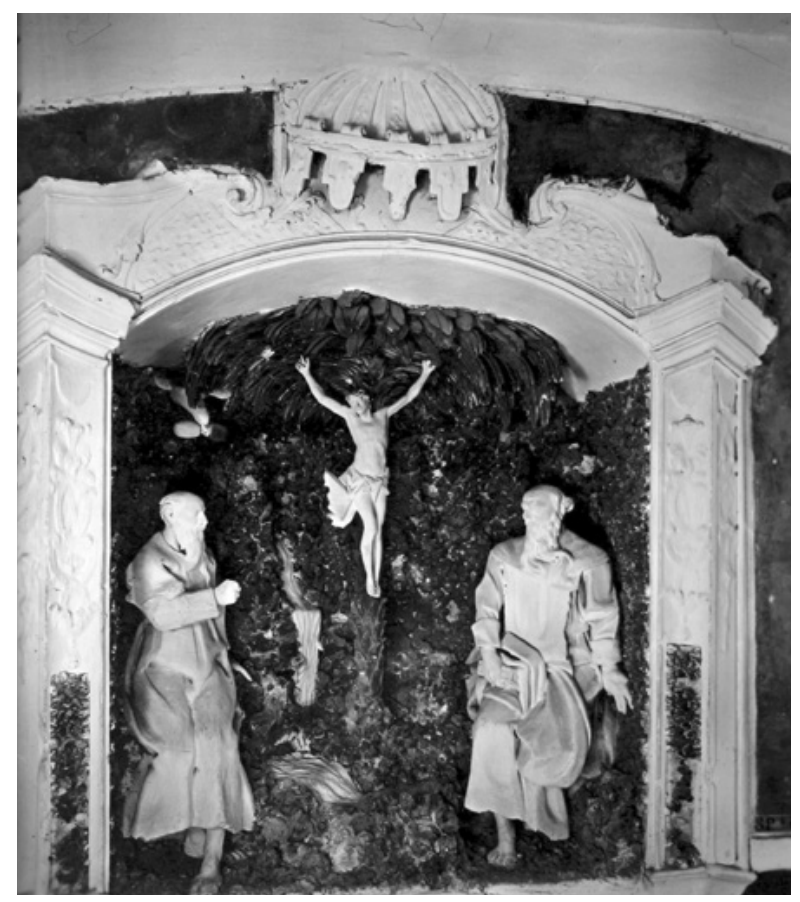

20. Grota na južnom zidu refektorija snimljena 1938. godine (fototeka Uprave za zaštitu kulturne baštine, snimio Đ. Griesbach, 1938.) Grotta on the refectory's south wall in 1938 (Ministry of Culture, Directorate for the Protection of Cultural Heritage, photo by $Ð$. Griesbach, 1938)

zao mali obelisk. Prema stilskim obilježjima, portal bi se mogao datirati u 17. ili prva desetljeća 18. stoljeća, dok su drvena vrata svakako iz kasnijeg vremena.

Refektorij je, prema samostanskom hodniku, bio osvijetljen i dvama prozorima, što je vidljivo na arhivskim nacrtima iz sredine 19. stoljeća. Sondama su utvrđene reške tih prozora na istočnom zidu, dok na strani hodnika nisu jasno raspoznatljive zbog popravka zidne građe prilikom zazidavanja te dersanja građe cementnom žbukom koja se teško skida. Ti prozori, prema formatu ukošene niše i oblikovanju prikazanom na nacrtima, bili su istovjetni s prozorom na zapadnom zidu zimskog refektorija koji je u obnovi 2003. - 2010. u cijelosti rekonstruiran. Vidljivo je da su prozori imali kamene okvire s ravnom nadstrešnicom te, kako se čini prema shematskom crtežu, stolariju s pravokutnim rasterom staklenih okana, premda je mogla biti riječ i o metalnim rešetkama. Presjek iz 1852 . ukazuje na to da su ispod južnog prozora, vjerojatno nakon zazidavanja, probijena vrata, a zbog tih vrata je $u$ nekom vremenu izveden armirano-betonski nadvoj, koji smo pronašli sondiranjem u zidu. ${ }^{56}$ Vrata, ili pak samo slijepa niša, postojala su još u vrijeme Drugog svjetskog rata, nakon čega su u cijelosti zazidana.

$\mathrm{Na}$ zapadnom zidu nalazi se šest prozora kojima su formati niša višekratno mijenjani zbog ugradnje prozorske stolarije. Krajnji desni (sjeverni) prozor prostorije $\mathrm{u}$ nekom je vremenu, naknadno, bio pretvoren $\mathrm{u}$ vrata, koja su potom zazidana. Na nacrtu iz oko 1850 . vidi se

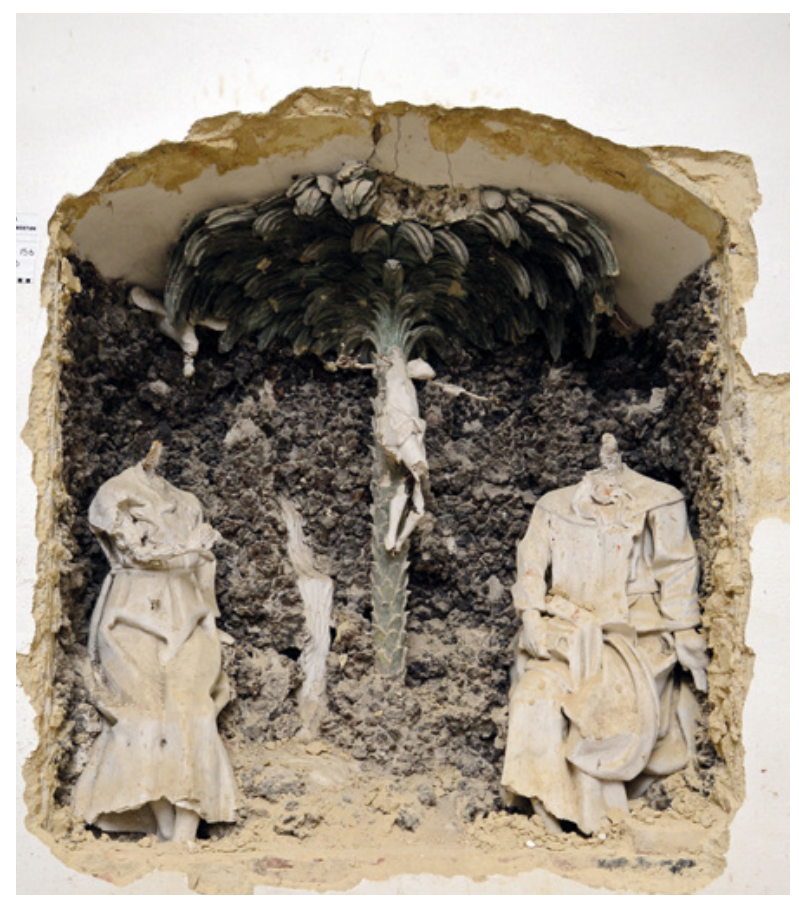

21. Odzidana grota s kipovima na južnom zidu refektorija tijekom istraživanja 2014. (fototeka HRZ-a, snimio J. Škudar, 2014.) The disclosure of the grotta with statues during the investigations in 2014 (Croatian Conservation Institute Photo Archive, photo by J. Škudar, 2014)

planirano zazidavanje te niše, a na Struppijevu nacrtu iz 1851. i Polivkinu iz 1852., kao i 1880., niša je već u cijelosti zazidana. Danas je tu ponovno prozor s visokim zidanim parapetom, jednak ostalim prozorima. Otvaranjem sondi u zoni parapeta ostalih prozora, utvrđeno je da se na njima nisu događale takve promjene te da su prozori zadržali visoki zidani parapet. ${ }^{57}$

Prostorija je danas nadstropljena, a kroz oštećenje $u$ stropu vidi se konstrukcija od željeznih traverzi. Izvorno se, dakle, u njoj nalazio svod, koji je uništen u potresu 1880. godine. Sondiranjem su pronađeni njegovi tragovi. Naime, na istočnom zidu utvrđeni su redovi opeke slagane ukoso, što predstavlja zazid nastao kao popravak zida nakon izbijanja donjih dijelova svodne konstrukcije iz zida (sl. 15). On se pojavljuje na istočnom zidu upravo $u$ okomitim potezima između zazidanih prozora i oslikanih luneta koji su bili smješteni u osi susvodnica. Na zapadnom zidu tragove svoda bilo je znatno teže utvrditi zbog naknadnog ojačavanja i pregradnje zida, premda se naziru i ondje..$^{58}$ Ispod navedenih zazida, osobito na istočnom zidu, pronađeni su tragovi obijenih žbukanih ornamenata, tzv. lambrekena (sl. 16), vidljivih na Quiquerezovoj skici iz 1878. godine. Lambrekeni imaju povijeni V-oblik, a dimenzije i proporcije im variraju ovisno o širini peta svoda. Zanimljivo je spomenuti da se slični lambrekeni nalaze $\mathrm{u}$ refektoriju dominikanskog samostana $\mathrm{u}$ Ptuju, no ondje svod, formom i dekorativnom obradom, znatno više podsjeća na lepoglavski zimski refektorij. 


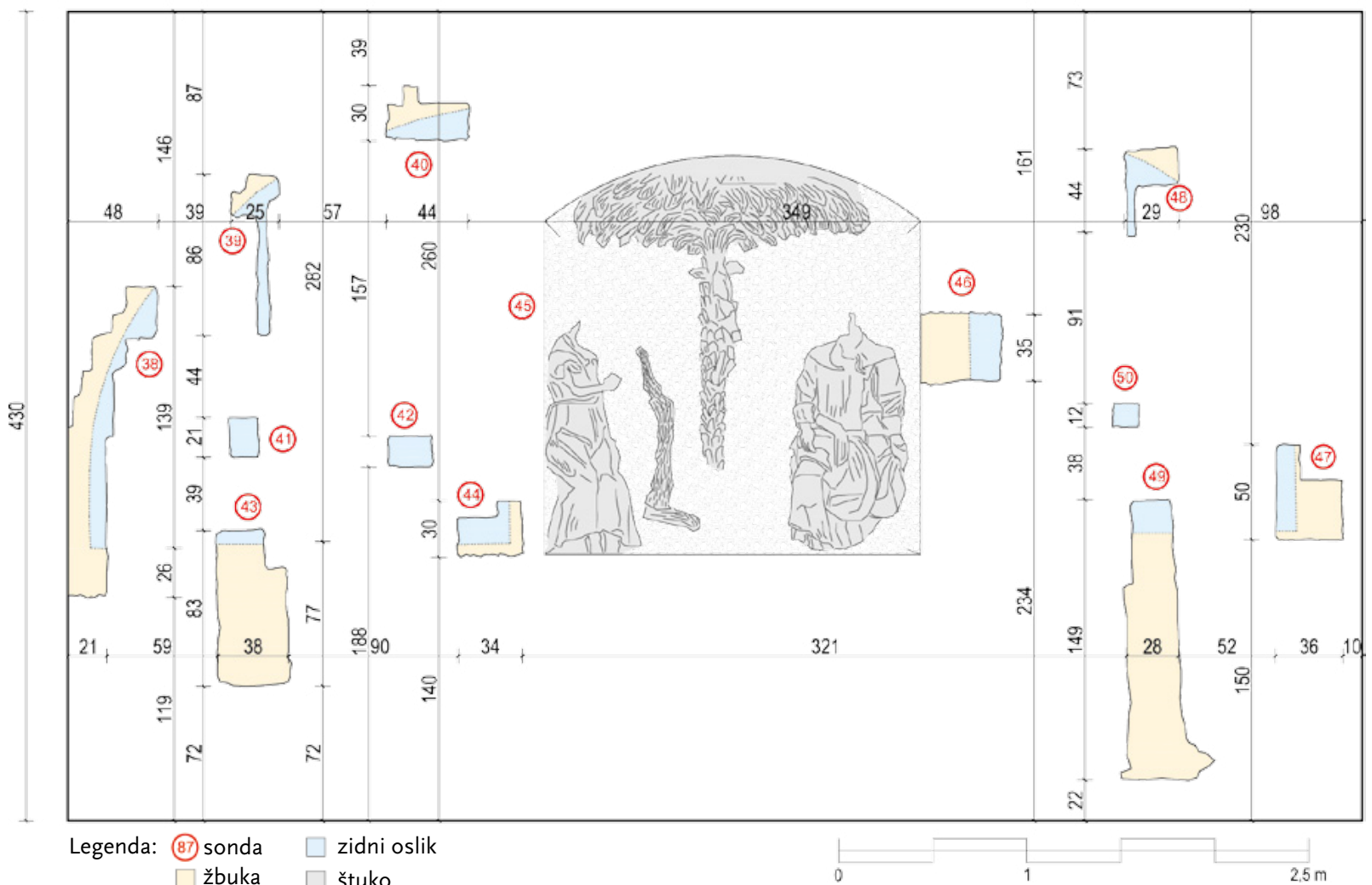

22. Grafički prikaz istražnih sondi otvorenih na južnom zidu refektorija (HRZ, izradili P. Puhmajer, B. Ratančić, M. Čalušić 2014.) Probes on the south wall (Croatian Conservation Institute, drawing by P. Puhmajer, B. Ratančić, M. Čalušić, 2014)

684

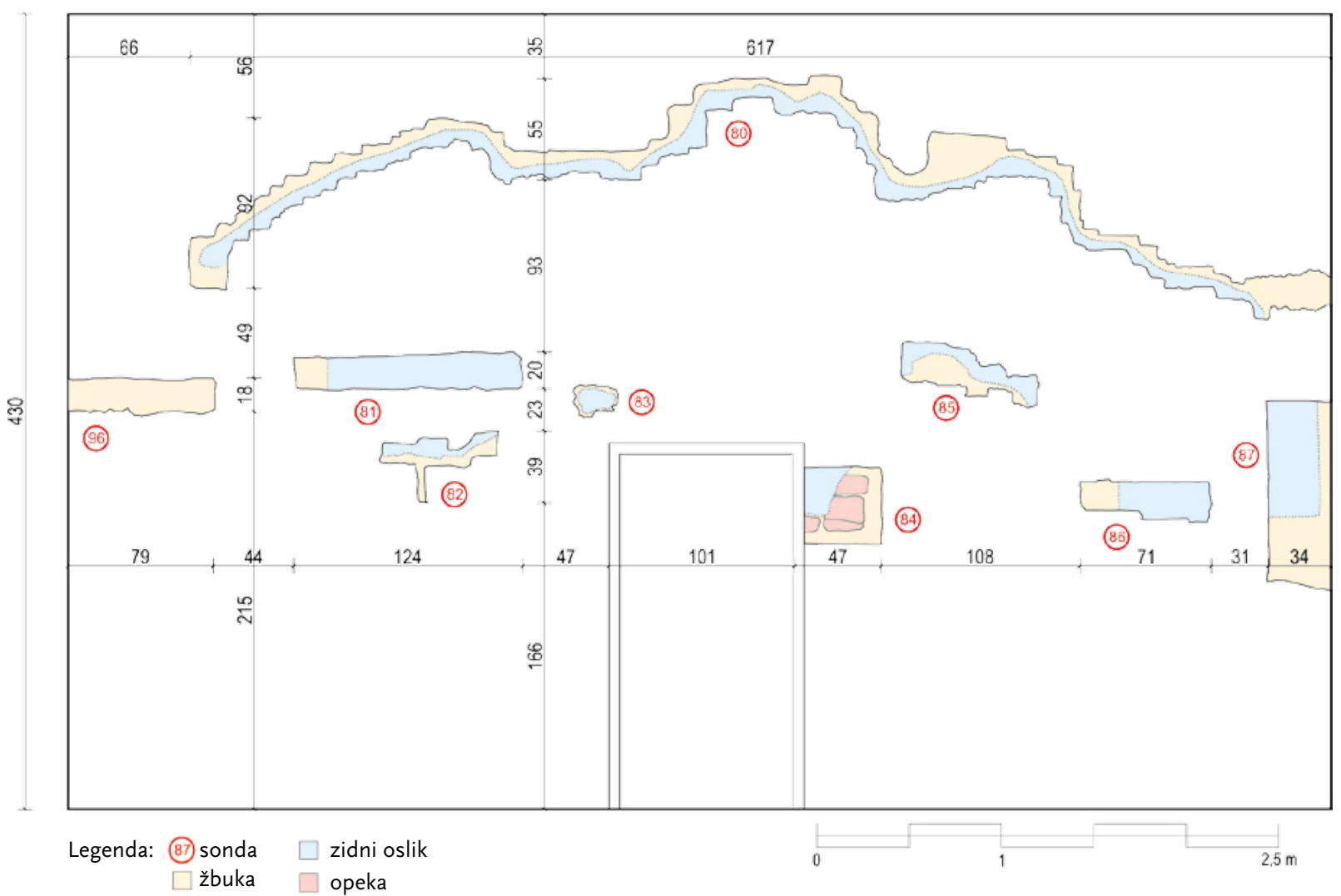

23. Grafički prikaz istražnih sondi otvorenih na sjevernom zidu ljetnog refektorija (HRZ, izradili P. Puhmajer, B. Ratančić, M. Čalušić 2014.) Probes on the north wall (Croatian Conservation Institute, drawing by P. Puhmajer, B. Ratančić, M. Čalušić, 2014) 


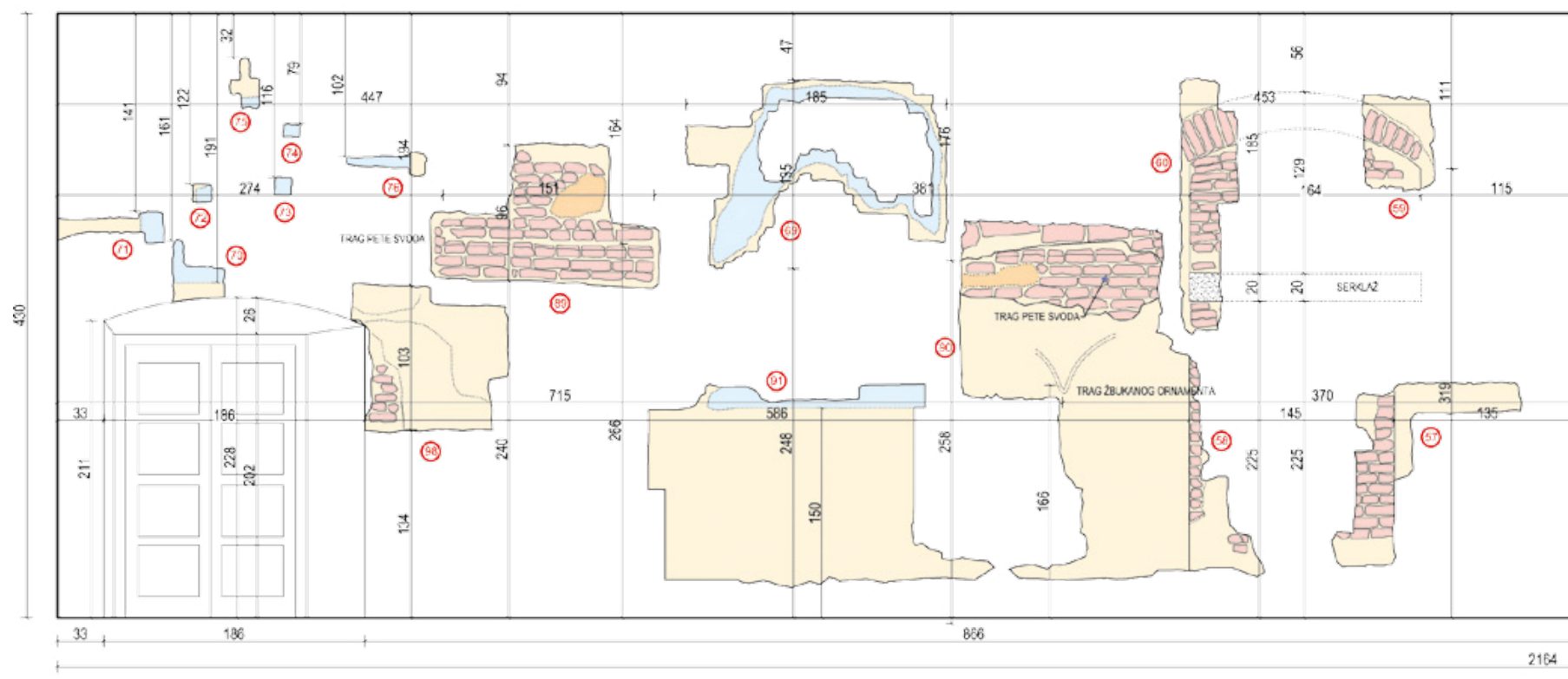

24. Grafički prikaz istražnih sondi otvorenih na istočnom zidu ljetnog refektorija (HRZ, izradili P. Puhmajer, B. Ratančić, M. Čalušić, 2014.) Probes on the east wall (Croatian Conservation Institute, drawing by P. Puhmajer, B. Ratančić, M. Čalušić, 2014)

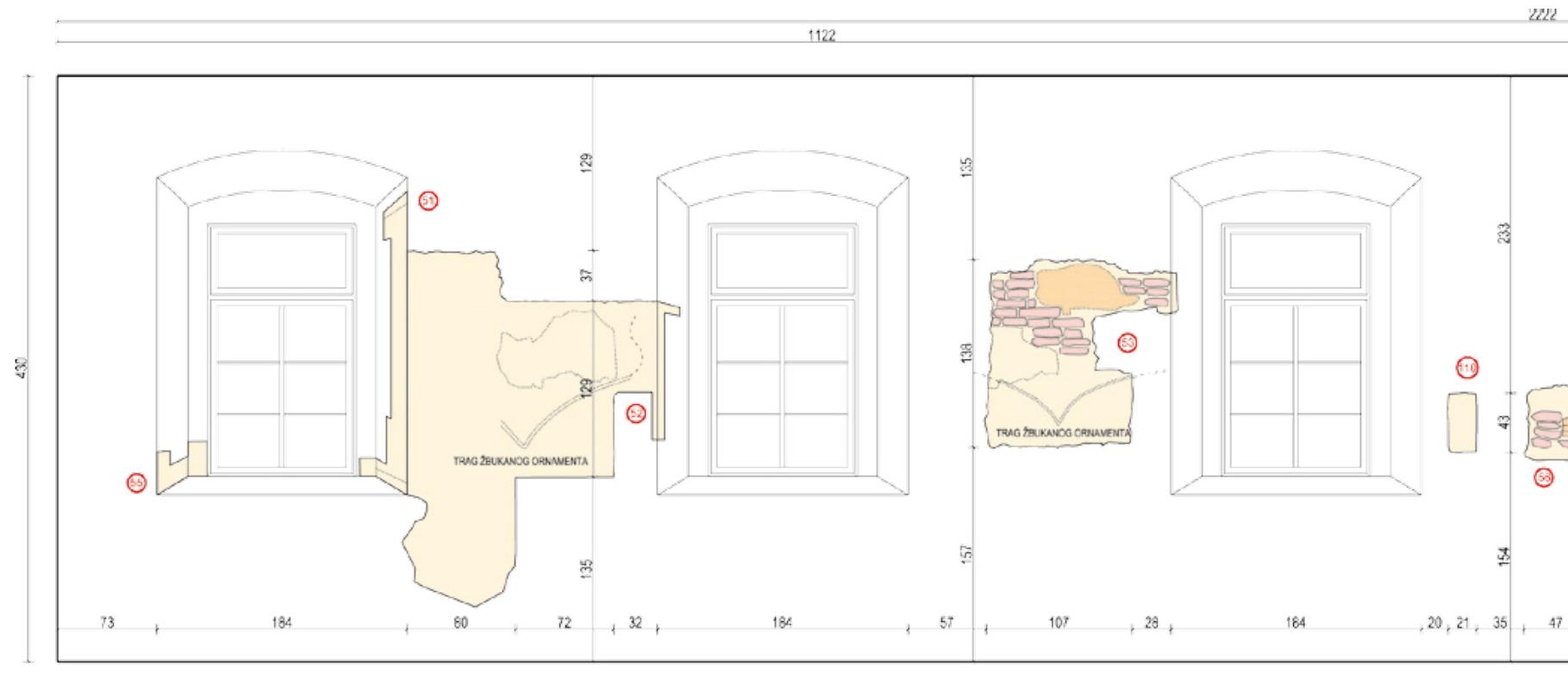

25. Grafički prikaz istražnih sondi otvorenih na zapadnom zidu ljetnog refektorija (HRZ, izradili P. Puhmajer, B. Ratančić, M. Čalušić, 2014.) Probes on the west wall (Croatian Conservation Institute, drawing by P. Puhmajer, B. Ratančić, M. Čalušić, 2014)

Zidni oslici, odnosno njihovi ostaci, pronađeni su na sjevernom, istočnom i južnom zidu. Sondiranjem se pokušao utvrditi stupanj očuvanosti oslika te su sonde otvarane ponajprije na rubnim područjima da bi se utvrdile dimenzije sačuvanih oslikanih površina (sl. 17), dok će daljnje otvaranje prethoditi restauratorskom postupku. $\mathrm{Na}$ istočnom zidu utvrđeni su dijelovi četiriju oslikanih medaljona, ${ }^{59}$ prema stanju na starim fotografijama, gdje se vide pravokutni medaljoni sa segmentnim zaključcima. Iznad ulaznih vrata utvrđena je oslikana površina koja odgovara medaljonu s prikazom vikara Pavla Ivanovića smještenom u kompoziciji naslikane arhitekture. Približne dimenzije utvrđenog oslika su 167 x $135 \mathrm{~cm}$. Desno od njega, nađeni su tragovi drugog oslikanog medaljona koji je slabije sačuvan. On se može povezati sa stojećim portretom biskupa Emerika Esterhazyja. Na otkrivenom segmentu vidljiv je natpis s godinom 1706. kad je Esterhazy proglašen vackim biskupom i godinom 1725. kad je postao nadbiskup Ostrogona. ${ }^{60} \mathrm{Na}$ istom zidu, u južnom dijelu prostorije, pronađeni su ostaci medaljona s likom 


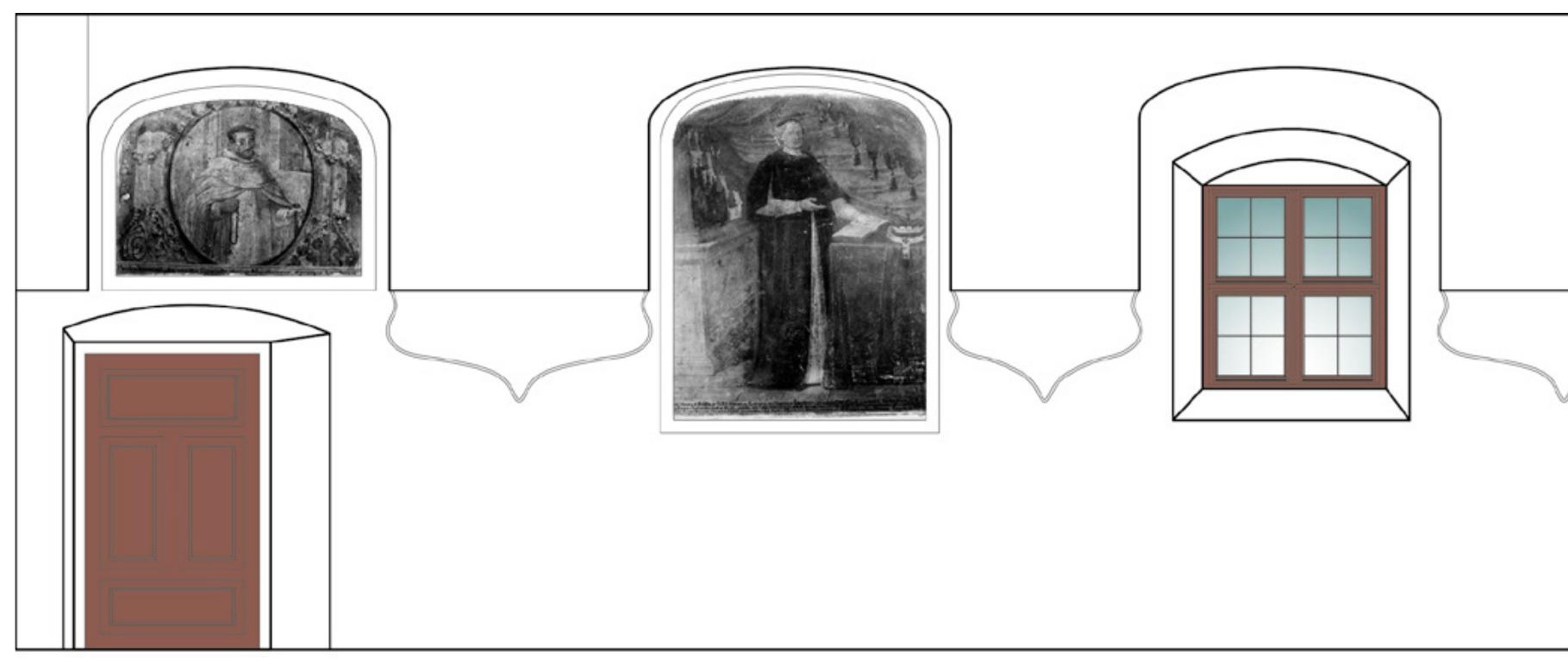

26. Grafički prikaz prijedloga prezentacije istočnog zida ljetnog refektorija (HRZ, izradili P. Puhmajer, B. Ratančić, M. Čalušić, 2014.) Presentation proposal of the refectory's east wall (Croatian Conservation Institute, drawing by P. Puhmajer, B. Ratančić, M. Čalušić, 2014)

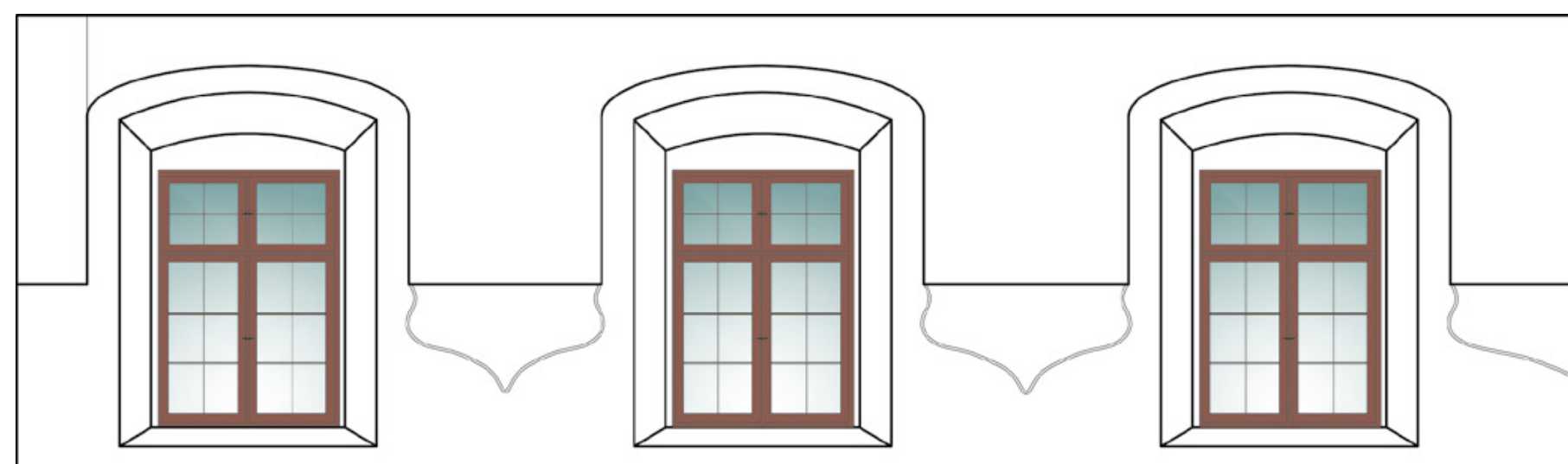

27 Grafički prikaz prijedloga prezentacije zapadnog zida ljetnog refektorija (HRZ, izradili P. Puhmajer, B. Ratančić, M. Čalušić, 2014.) Presentation proposal of the refectory's west wall (Croatian Conservation Institute, drawing by P. Puhmajer, B. Ratančić, M. Calušić, 2014)

je da je na lijevoj (istočnoj) strani lunete bio naslikan sv. Augustin, a na desnoj (zapadnoj) sv. Jeronim.

Niša, odnosno grota usred lunete, tijekom istraživanja je u cijelosti odzidana (sl. 20, 21). U njoj su djelomično sačuvane skulpture sv. Pavla i sv. Antuna između kojih je raspelo, a pozadina i kalota ispunjene su stiliziranim stjenovitim pejzažem. Sva dekoracija izvedena je u štuku. Grota je izvorno imala profilirani žbukani okvir s dva četvrtasta polustupa koje je nadvisivao dekorativni zabat s malim baldahinom. Niša je bila zazidana 30 . travnja 1947. godine, kako je to olovkom zapisano na jednom od kipova, a tada je vjerojatno i otučen cijeli arhitektonski okvir. $^{64}$
Sondažna istraživanja detaljno su opisana i fotografski dokumentirana. Dokumentacija sadrži i grafičke prikaze svih zidova refektorija s ucrtanim položajem sondi i nalaza slikanih površina, kako bi trajno bila zabilježena njihova sačuvanost $u$ današnjem vremenu te kako bi se olakšalo njihovo buduće cjelovito otkrivanje skidanjem slojeva žbuke (sl. 22, 23, 24, 25).

\section{Pitanje prezentacije refektorija}

U konzervatorskom elaboratu za istočno, južno i zapadno krilo iznesene su smjernice za obnovu ljetnog refektorija. Općenito je prezentacija cijelog samostana još od prvih istraživanja 2003./2004. bila usmjerena na 

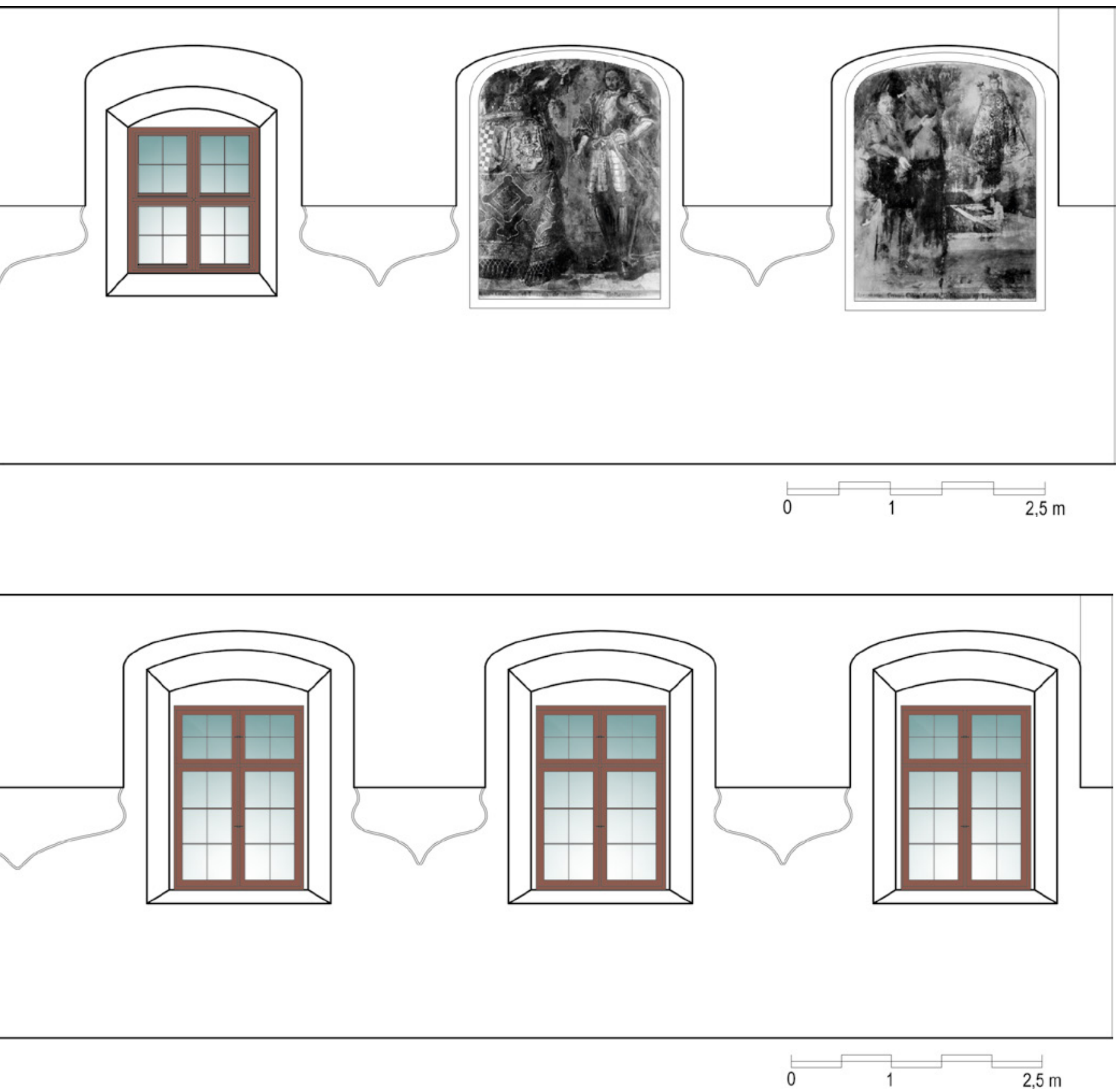

vraćanje pavlinske faze samostana, što je značilo zaista velike rekonstrukcijske zahvate $u$ građevinskom smislu, dok se kod zidnih slika i štukatura nastojalo prije svega obnoviti sačuvano, bez većih dopuna i restitucija. Tako je i u smjernicama za obnovu ljetnog refektorija cilj bio vratiti njegove izgubljene vrijednosti koliko je to objektivno moguće, $u$ arhitektonskom smislu u većoj mjeri, a dekorativna obrada ponajprije unutar onoga što je sačuvano (sl. 26, 27, 28, 29). ${ }^{65}$

Preporučeno je uklanjanje pregradnog zida između dviju prostorija kako bi se dobio jedinstven prostor refektorija, kao i njegovo popločenje kamenim pločama. Najvažniji je zahvat rekonstrukcija svoda (sl. 30); odluka se teme- lji na dosadašnjim radovima na obnovi samostana, kao i na prije iznesenim prijedlozima prezentacije za druga samostanska krila. Za svod je nužno izraditi građevinski projekt, a prilikom njegove izvedbe treba u najvećoj mjeri sačuvati i prezentirati zatečene tragove oslika na zidovima. ${ }^{66} \mathrm{U}$ dvije središnje lunete istočnog zida predviđeno je odzidavanje prozorskih niša te oblikovanje kamenih prozora sa strane hodnika, kao i portala na ulazu. Nužna je i rekonstrukcija žbukanih ornamenata ispod peta svoda, kao i potpuna rekonstrukcija niše sa štuko kipovima na južnom zidu, kako štukatura, tako i njezina arhitektonskog okvira. Izgled niše i njezina okvira može se, prema povijesnim fotografijama, u cijelosti rekonstruirati s ve- 


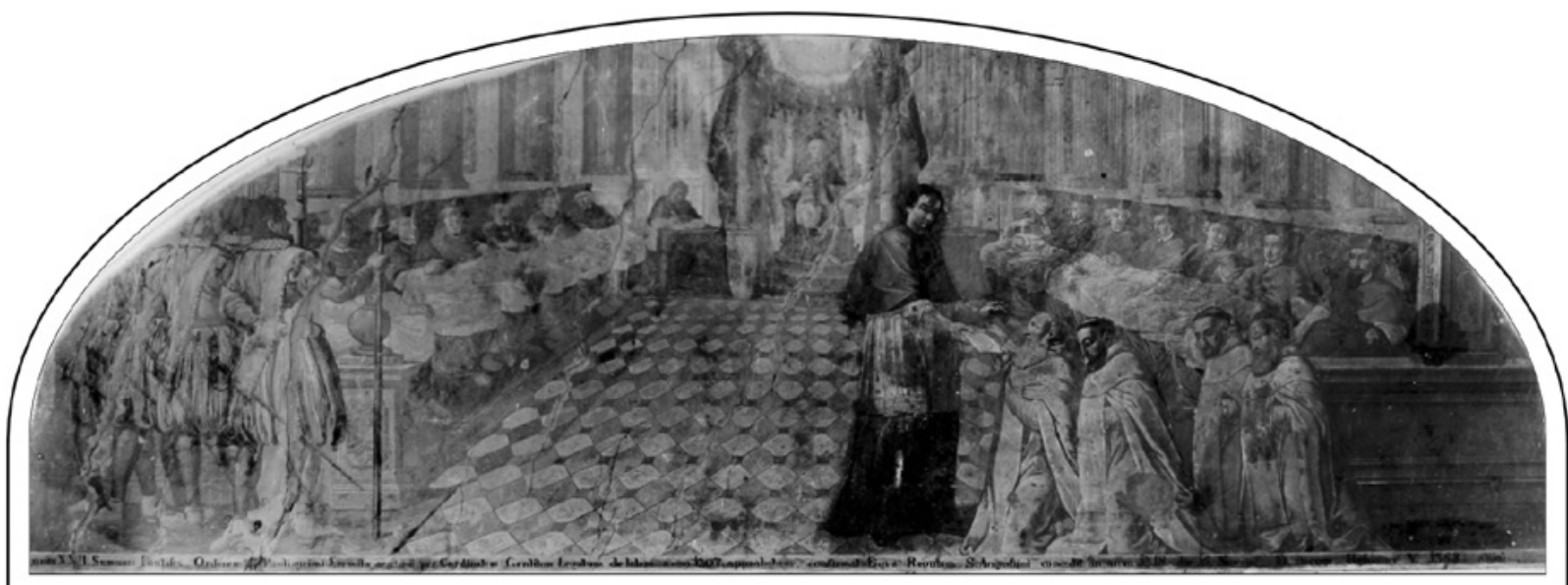

28. Grafički prikaz prijedloga prezentacije sjevernog zida ljetnog refektorija (HRZ, izradili P. Puhmajer, B. Ratančić, M. Čalušić, 2014.)

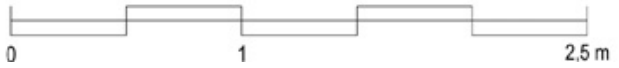
Presentation proposal of the refectory's north wall (Croatian Conservation Institute, drawing by P. Puhmajer, B. Ratančić, M. Čalušić, 2014)

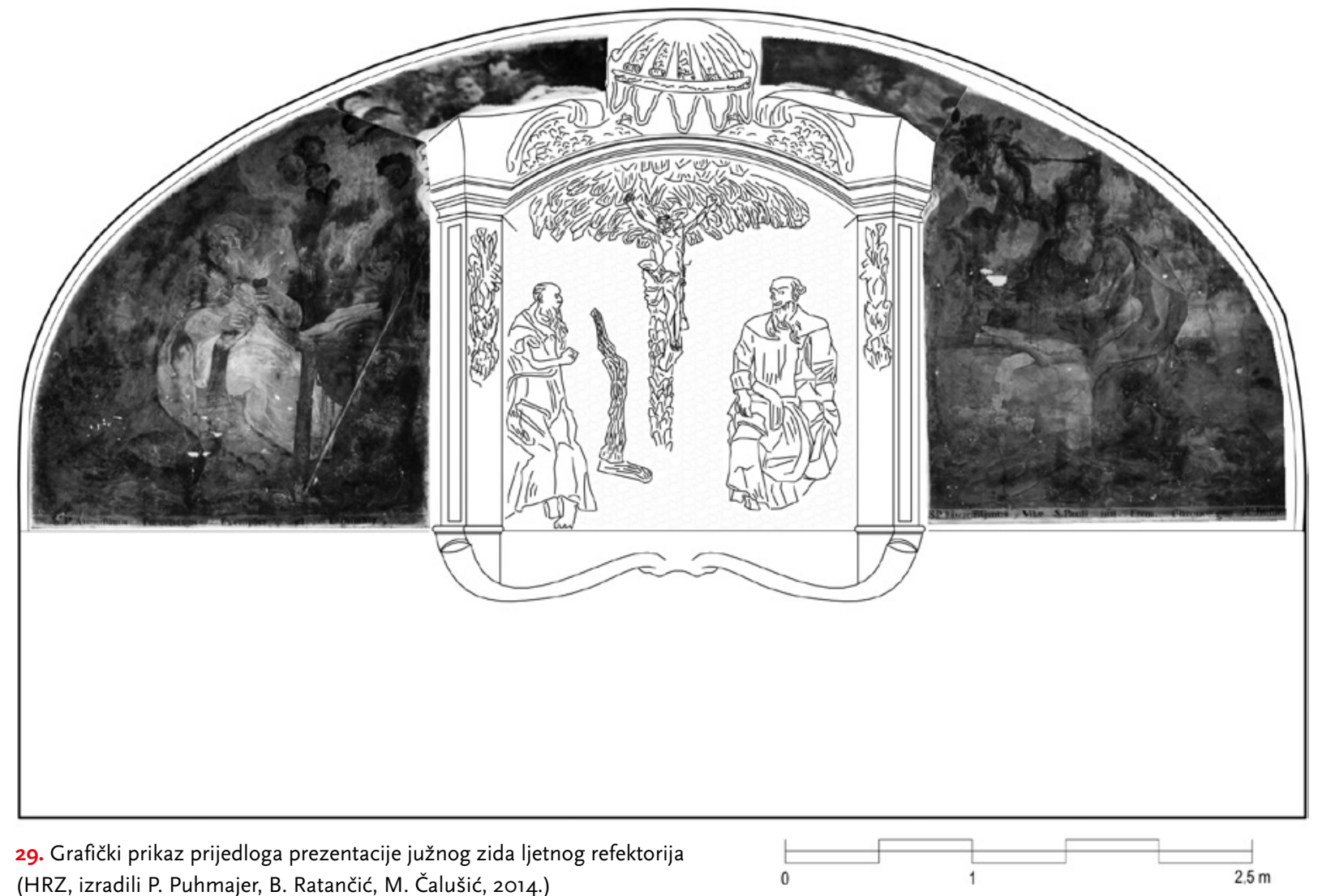

(HRZ, izradili P. Puhmajer, B. Ratančić, M. Čalušić, 2014.)

Presentation proposal of the refectory's south wall (Croatian Conservation Institute, drawing by P. Puhmajer, B. Ratančić, M. Čalušić, 2014) 

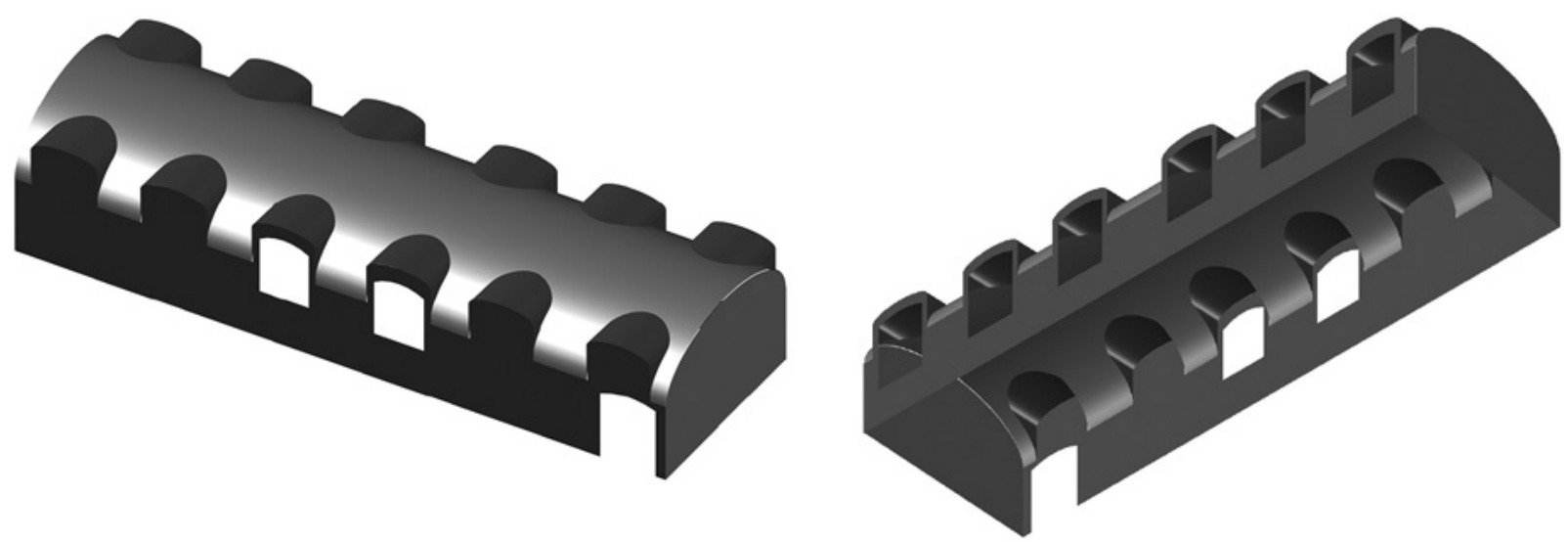

30. Trodimenzionalni model rekonstrukcije svoda u refektoriju (HRZ, izradila I. Popović, 2015.)

Three-dimensional model of the vault reconstruction (by Ivana Popović, Croatian Conservation Institute, 2015)

likom preciznošću, ali je potrebno prije toga pripremiti izvedbenu grafičku dokumentaciju.

Zidne slike u medaljonima na istočnom zidu te veliki naslikani prizori u lunetama sjevernog i južnog zida zahtijevaju opsežan restauratorski postupak, a moguć je i retuš nedostajućih dijelova prema povijesnim fotografijama, o čemu će se odlučiti tijekom restauratorskog postupka. Iako se na svodu također nalazila štukatura i zidni oslik, nije preporučena njihova rekonstrukcija, već samo bijeljenje plohe. Kao iznimka je ostavljena mogućnost da se u žbuci izvedu uleknuti trolisni medaljoni $u$ susvodnicama te pravokutna polja na svodu, kao referenca na nekadašnji oslik, ali bez oslikavanja; sve površine obojile bi se u bijelo.

Problem obnove refektorija je višestruk. Pošli smo od temeljne činjenice da su razmjeri uništenja bili iznimno veliki, pa je najvažnije bilo odrediti stupanj očuvanosti arhitektonskih i dekorativnih elemenata. Budući da za brojne elemente postoji vrlo dobra dokumentacija (slikovna, grafička i dr.), rekonstrukcija refektorija u njegovu izvornom obliku je teorijski moguća u velikoj mjeri. Štoviše, u cijelosti se može obnoviti slikana i arhitektonska dekoracija zidova pa je, uzimajući u obzir i stanje očuvanosti, to i predloženo u elaboratu. Temeljem koncepta dosadašnje obnove Lepoglave, preporučena je i rekonstrukcija svoda, kao najvažnijeg elementa arhitekture refektorija. Unatoč tome što je njegov ukras poznat s Quiquerečeva akvarela, ponovno ukrašavanje zidnim slikama i štukaturom nije preporučeno jer bi ono bilo zaista velik rekonstrukcijski zahvat. Pri tome bi brojni detalji, poput boje oslika ili pak debljine štukatura, morali biti proizvoljno određeni. Nadalje, Quiquerečev akvarel, koliko god bio vjeran originalu, ipak nije izvorni dokument, kakav bi, primjerice, bila fotografija da je sačuvana, pa bi takvo oslikavanje značilo rekonstrukciju prema sekundarnim izvorima. Takvim pristupom obnovi, u ukupnom rezultatu suočili bismo se sa znatnim manjkom autentičnosti prostora. Složeni i opsežni zahvati obnove lepoglavskog samostana i crkve dosad su bili vođeni uz poštivanje konzervatorske etike u najvećoj mogućoj mjeri, pa je svakako važno voditi se sličnim načelima i u obnovi refektorija. Ljetni refektorij jest zasebna, ujedno i iznimno vrijedna, arhitektonskoumjetnička cjelina, gdje ne bi valjalo raditi nužne kompromise uobičajene u konzervatorskoj struci, već slijediti pomno osmišljen koncept obnove i primjenjiv metodološki postupak.

\section{Bilješke}

1 IVAN KUKULJEVIĆ SAKCINSKI, Bericht über einige Baudenkmale Croatiens, Mitteilungen der K.K. Central-Commission, 1, 1856., 232-237; IVAN KUKULJ EVIĆ SAKCINSKI, Slovnik umjetnikah jugoslavenskih, Zagreb, 1858., 236.

2 Ivan Krstitelj Krapac je u Zagrebačkom katoličkom listu objavio više kraćih tekstova o povijesti lepoglavskog samostana. O zidnim slikama u ljetnom refektoriju piše na prvim stranicama brojeva objavljenih 12. i 19. svibnja 1870. IVAN KRSTITELJ KRAPAC: Samostan ljepoglavski. Historič- ka crta, Zagrebački katolički list, XXI, Zagreb, četvrtak 12. svibnja 1870., 165-168; i četvrtak 19. svibnja 1870., 173-175. 3 ŠıME LJUBIĆ, Arkeologičke crtice iz moga putovanja iz njekojih predjelih Podravine i Zagorja god. 1879., Vjesnik Arheološkog muzeja u Zagrebu 2, 1880., Zagreb, 110-120. 4 IZIDOR KRŠNJAVI, Lepoglavske umjetnine, Vienac 50, 1878., Zagreb, 802-804.

5 ROBERTO KAUk, Poviest paulinskoga samostana i sadašnje kraljevske zemaljske kaznione u Lepoglavi, Vukovar, 1895. 
6 GJURo SZABo, Spomenici kotara Ivanec, Zagreb, 1919. 7 MARIJA MIRKOVIĆ, Slikarstvo lepoglavskih pavlina, Kaj, VI, 1979. te MARIJA MIRKOVIĆ, Ikonografski program ljetne blagovaonice u Lepoglavi, Lepoglavski zbornik 1994., 1995., 87-98.

8 TOMISLAV PUGELNIK, Zidne slike u ljetnoj blagovaonici bivšega pavlinskoga samostana u Lepoglavi, Tkalčić Godišnjak Društva za povjesnicu Zagrebačke nadbiskupije, 12, 2008., 467-508.

9 Samostan se gradi od 1681. do 1696., a imao je i zimski i ljetni refektorij. Ljetni refektorij u južnom krilu ukrašen je 1693. štukaturom koju su izveli majstori Jožef Anton Quadrio i Peter Bettini. MARJETA CIGLENEČKı, Samostanska oprema v preteklosti, Minoritski samostan na Ptuju 1239 - 1989, ur. Jože Mlinarič, Marjan Vogrin, Ptuj - Celje, 1989., 327-329.

10 Petar Puhmajer, teodora KUČınac, Pročelja pavlinskog samostana u Lepoglavi, Radovi Instituta za povijest umjetnosti, 32, 2008., 151-166; PETAR PUHMAJER, Izgradnja i preobrazbe kompleksa pavlinskog samostana i crkve sv. Marije u Lepoglavi, Godišnjak zaštite spomenika kulture Hrvatske, 37-38, 2013./2014., 81-99.

11 Sakristija se nalazi uz svetište crkve, u istočnom samostanskom krilu. NIKOLA BENG ER, Synopsis historico-chronologica Monasterii Lepoglavensis ordinis S. Pauli primi ermitae provinciae Croatico-Slavonicae, rukopis, sign. II-a-22, Arhiv HAZU-a, Zagreb. Anno 1650.: „Per vicarium Ivanovich erigi capit nova structura monasterij Lepoglav. primusis lapis pro nova sacristia posintus die 7. Aprili sin loco actualis sacristia (...). E. a. 2ta vice in Generale electus est P. Martin Borkovich, sed post anu resignavit.“

12 IVAN KRIŠTOLOVEC, Descriptio synoptica Monasteriorum ordinis S. Pauli primi Eremiae in Illyrico, Liber memorabilium parochiae Lepoglavensis ab Anno 1401 usque 1789, rukopis, Arhiv HAZU-a, Zagreb (nedatirano), 118; NIKOLA BENGER, (bilj. 11), anno 1650.

13 „E. A. satagente P. Vicario Solary surexit in notabili Perfectione nova lepoglavensis monasterii fabrica, erecto tractu Septentrionali, item Orientali, quem P. Ivanovich eduxerat con camerationibus formato. Idem P. Vicarius renovavit Ecclesiam, et Aram majorem que hodie stat apposuit." NIKOLA BENGER, (bilj. 11), anno 1663.

14 Zapadno je krilo sagrađeno zaslugama vikara Nikole Nagyja i Nikole Klančeca te generala pavlinskog reda Ivan Keryja. „Porro tractus Occidentalis Monasterii erectus est circa anno 1673." NIKOLA BENGER, (bilj. 11), anno 1663; IVAN KRIŠTOLOVEC, (bilj. 12), 118.

15 IVAN KRIŠTOLOVEC, (bilj. 12), 118. Prijevod s latinskog: dr. sc. Šime Demo.

16 Sama činjenica što je zimski refektorij manji od ljetnoga govori da se prilikom projektiranja već predviđalo njegovo grijanje u zimskim mjesecima, dok za ljetni refektorij to ne možemo tvrditi.
17 „Eodem anno Illmus Dnus Comes Joannes Pethö Refectorium Lepoglavense opera celaturae gypsariae ornari curavit intermixtis pulchri laboris Iconismis, signanter miracula s. Pauli primi Eremitae exhibentibus, adjectis versibus poeticis." NIKOLA BENGER, (bilj. 11), anno 1722. 18 ,Item eodem anno Refectorium aestivum restauratum est picturis novis in fornice et arcubus, item novo strato marmoreo, atque hoc partim impensis Conventus, partim subsidio, dato a Rssmo P. Stephano Demsich, emerito Generali, partim ab A. R. Patre Andrea Musar Provinciali.“ NIKOLA BENGER, (bilj. 11), anno 1733.

19 Najranije je zabilježena gradnja svoda u istočnom, a možda i sjevernom krilu oko 1663. „E. A. satagente P. Vicario Solary surexit in notabili Perfectione nova lepoglavensis monasterii fabrica, erecto tractu Septentrionali, item Orientali, quem P. Ivanovich eduxerat, con camerationibus formato." NIKOLA BENGER, (bilj. 11), anno 1663. No nije posve sigurno na koje se svodove zapis odnosi, s obzirom na to da se u hodniku prvog kata sjevernog krila gradnja svodova spominje tek 1733., u drugom katu 1735., a kasne 1747. na hodniku drugoga kata istočnog krila. NIKOLA BENGER, (bilj. 11), anno 1733, anno 1735, anno 1747.; KAMILO DOČKAL, Povijest pavlinskog samostana bl. Djevice Marije u Lepoglavi, Zagreb, 2014., 395.

20 „In mense Aprili appositum est novum tectum in media parte tractus orientalis monasterii supra refectorium hÿemale." Usp. NIKOLA BENGER, (bilj. 11), anno 1734. Pet godina poslije zimski je refektorij ukrašen slikama. „Hoc anno Refectorium hyemale renovatum novis picturis." $\mathrm{NI-}$ KOLA BENGER, (bilj. 11), anno 1739.

21 MARIJA MIRKOVIĆ, 1979., (bilj. 7), 26-28; MARIJA MIRKOVIĆ, 1995., (bilj. 7), 90.

22 ROBERTO KAUK, 1895., (bilj. 5), 77-79.

23 Petar puhmajer, 2013./2014., (bilj. 10).

24 U krapinskom je refektoriju nedavno obijena sva žbuka pa se mogla vidjeti građa svoda. Zanimljivo je primijetiti da se u zaključku svake susvodnice nalazi drvena greda koja služi kao ojačanje, a ujedno formira i ravan brid tlocrtno pravokutne susvodnice. Te grede su po svoj prilici nastale u vrijeme gradnje svoda, s obzirom na to da se u zidanoj građi ne vide oštećenja koja nastaju naknadnom ugradnjom.

25 DRAGINJA JURMAN-KARAMAN, Ivan Kukuljević-Sakcinski: prvi konzervator za Hrvatsku i Slavoniju, Zbornik zaštite spomenika kulture, 4-5, Beograd, 1955., 147-162: 149. 26 IVAN KUKULJEVIĆ SAKCINSKI, 1856., (bilj. 1), 236; IVAN KUKULJEVIĆ SAKCINSKI, 1858., (bilj. 1), 365. Gjuro Szabo smatra da je Kukuljević pomiješao portrete iz ljetnog i zimskog refektorija, vjerojatno zato što neke likove spominje u oba refektorija. Držimo da su važne osobe mogle biti prikazane u oba refektorija, pogotovo zato što se radi o utemeljiteljima i obnoviteljima samostana, a u prilog tomu ide i činjenica da je Kukuljević uživo vidio slike koje 
su još tada postojale, a Szabo ih više nije mogao vidjeti. Usp. GJURO SZABO, 1919., (bilj. 6), 25.

27 ŠıME LJUBıć, 1880., (bilj. 3), 118.

28 Kršnjavi navodi da je na središnjoj slici prikazana Posljednja večera, s jedne strane je gozba u Kani Galilejskoj, dok je scenu s druge strane opisao kao „uzapćenje nekoga mladića pri jednoj gostbi“. IZIDOR KRŠNJAVI, 1878., (bilj. 4), 802.

29 Kršnjavi je prilikom identificiranja prikaza pomiješao likove sv. Pavla i sv. Antuna. TOMISLAV PUG ELNIK, 2008., (bilj. 8), 483-484.

30 Kršnjavijev izvještaj je prvi kritički osvrt na lepoglavske zidne slike, iako se primjećuju određene nejasnoće i nedosljednosti, posebice vezano uz atribuciju slika. ızıDOR KRŠNJAVI, 1878., (bilj. 4), 802-803. Na te nelogičnosti među prvima ukazuje Gjuro Szabo, a poslije i Kamilo Dočkal. GJURO SZABO, 1919., (bilj. 6), 25-28; KAMILO DOČKAL, 2014., (bilj 19), 203. Najdetaljniji pregled rasprave o stilu i atribuciji lepoglavskih fresaka donosi Pugelnik. TOMISLAV PUGELNIK, 2008., (bilj. 8), 500-501.

31 IZIDOR KRŠNJAVI, 1878., (bilj. 4), 8O2.

32 Zanimljivo je primijetiti stav Izidora Kršnjavoga prema baroknoj umjetnosti, kada navodi da je središnja scena Posljednje večere „slikana valjda ponajkašnje, jer joj je slog već posvema izkvaren i barokan tako, da u slike ne ima do dekorativne vriednosti“, te dalje u opisu bočnih slika:,(...) takodjer su dekorativno radjene ali imade zanimljivih glava i dobro prem dekorativno i barokno zamišljenih draperija“. IZIDOR KRŠNJAVI, 1878., (bilj. 4), 802-803.

33 IZIDOR KRŠNJAVI, 1878., (bilj. 4), 803.

34 Cijeli crtež svoda i preslikana tri medaljona objavljena su u: tOMISLAV PUGELNIK, 2014., (bilj. 8).

35 TOMISLAV PUGELNIK, 2014., (bilj. 8)., 495-496.

36 Pugelnik dvoji je li štukatura plastički oblikovana ili „iluzionirana“, što bi moglo značiti da je naslikana. Usp. TOMISLAV PUGELNIK, 2014., (bilj. 8)., 488. Štukatura je na svodu svakako postojala, o čemu svjedoči zapis iz 1722. („celatura gypsaris“), a spominje ju i Kršnjavi. Štukatura je mogla biti plastički istaknuta ili urezana, kao što je to slučaj u zimskom refektoriju.

37 ŠıME LJUBIĆ, 1880., (bilj. 3), 118.

38 JOSIP TORBAR, Izvješće o zagrebačkom potresu 9. studenoga 1880., Zagreb, 1882., 65.

39 Petar puhmajer, 2013./2014. (bilj. 10), 94.

$40 \mathrm{Na}$ gornjim etažama sjevernog krila uspostavljen je novi središnji hodnik, uz koji su se s obje strane nizale ćelije. S obzirom na to da je do takvog zahvata moglo doći samo uklanjanjem postojećih svodova, pretpostavlja se da su svodovi stradali u potresu. PETAR PUHMAJER, 2013./2014. (bilj. 10), 94; Petar Puhmajer, Lepoglava. Pavlinski samostan. Elaborat konzervatorsko-restauratorskih istraživanja istočnog, južnog i zapadnog krila, Hrvatski restauratorski zavod, Zagreb, 2014., 17.
41 ROBERTO KAUK, 1895., (bilj. 5), 44-45. Isto navodi i Gjuro Szabo, koji obilazi lepoglavski samostan početkom 20. stoljeća. GJURO SZABO, 1919., (bilj. 6), 25-28.

42 ARTUR SCHNEIDER, Popisivanje i fotografijsko snimanje umjetničkih spomenika godine 1938., Ljetopis JAZU, 51,168-180; ARTUR SCHNEIDER, Popisivanje i fotografijsko snimanje umjetničkih spomenika godine 1938., Ljetopis JAZU, 52, 171-186.

43 FERDO LADIKA, Izvješće o spaljenom i srušenom bivšem pavlinskom samostanu u Lepoglavi te o stanju tamošnjih kuturno historijskih i umjetničkih spomenika, rukopis u Ministarstvu kulture - Uprava za zaštitu kulturne baštine Topografska zbirka: Lepoglava, općina Ivanec, Lepoglava, (dalje мK-UZKB-TZ: Lepoglava, općina Ivanec), 1944., 3. 44 Ladika je tom prilikom preslikao tri zidne slike, koje su se vjerojatno nalazile u zimskom refektoriju (Raspeće s dva pavlina, tri anđeoske glavice i poprsje pavlina s prstom na ustima), Raspeće koje se nalazilo na vanjskom zidu sakristije $u$ istočnom krilu i portret Ivaniša Korvina iz ljetnog refektorija. M K-UZKB-TZ: Lepoglava, općina Ivanec, Dopis o kopijama propalih freski u Lepoglavi, sastavio Ljubo Karaman, Zagreb, 9. rujna 1947.

45 FERDO LADIKA, 1944., (bilj. 43), 4.

46 Isto, 2.

47 Ladika atribuira sačuvane zidne slike pavlinskim slikarima Franji Bobiću (portret Pavla Ivanovića) i Ivanu Rangeru. FERDO LADIKA, 1944., (bilj. 43).

48 FERDO LADIKA, 1944., (bilj. 43), 5.

49 M K-UZKB-TZ: Lepoglava, općina Ivanec, Zagreb, Pregradnje i novogradnje Kazneno-popravnog doma u Lepoglavi, sastavio Ljubo Karaman, 8. travnja 1946.

50 Prema sačuvanoj dokumentaciji Konzervatorskog zavoda u Zagrebu, zidne su slike ljetnog refektorija bile nezaštićene još sredinom 1946. godine. MK-UZKB-TZ: Lepoglava, općina Ivanec, Zapisnik, sastavio Vinko Bregović, Lepoglava, 17. svibnja 1946.

51 Radovi na sanaciji crkvenog pročelja i knjižnice počeli su 1946. godine, no zbog niza otežavajućih okolnosti, nisu nastavljeni do 1950. godine, a daljni radovi počeli su tek 1952. godine. GRETA JURIŠıĆ, Konzervatorski radovi na pavlinskom samostanu i crkvi u Lepoglavi, Zbornik zaštite spomenika kulture 4-5, Beograd, 1955., 392-396: 395.

52 M K-UZKB-TZ: Lepoglava, općina Ivanec, Pregradnje i novogradnje Kazneno-popravnog doma u Lepoglavi, 1946., sastavio Ljubo Karaman, Zagreb, 8. travnja 1946.

53 м K-UZKB-TZ: Lepoglava, općina Ivanec, Izvještaj o službenom putovanju konzervatora dr. Ljube Karamana, asistenta Mladena Fučića i restauratora slika prof. Zvonimira Wyroubala u Lepoglavu dne 9. i 10. srpnja 1947., Zagreb, 1947. 54 Istraživanja, koja je vodio akademik Vladimir Marković, opisana su u izvještaju: VLADIMIR MARKOVIć i sur. (2004): Pavlinski samostan u Lepoglavi, Izvješće o konzervatorsko-restauratorskim istraživanjima u sjevernom i dijelu 
istočnoga krila te prijedlog smjernica za njihovu obnovu, sv. I i II, Hrvatski restauratorski zavod, Zagreb.

55 Istraživanja je vodio Petar Puhmajer, a u radnom timu su sudjelovali: Bernarda Ratančić, Anđelko Pedišić, Miroslav Jelenčić, Marina Fernežir i Tomica Paradi. Grafička obrada nacrta: Ivana Popović i Marin Čalušić. Fotodokumentacija: Jurica Škudar. Za istraživanja su korištene snimke postojećeg stanja koje je izradila tvrtka Ateh d.o.o. Istraživanja su opisana u elaboratu: PETAR PUHMAJER, 2014., (bilj. 40).

56 Petar Puhmajer, 2014., (bilj. 40), 245.

57 Isto, 246.

58 Isto, 246.

59 Isto, 246.

60 ANTE SEKULIĆ, Pavlinski vrhovni poglavari, Kultura pavlina u Hrvatskoj 1244. - 1786., katalog izložbe (Zagreb, Muzej za umjetnost i obrt, 12. svibnja - 31. listopada 1989.), Zagreb, 1989., 373-376: 376.

61 Nije posve jasno koji je papa prikazan na sceni. Pavlinima je Pravilo sv. Augustina dao papa Klement V. 1308. godine, a bulama su ih potvrdili pape Ivan XXII., Klement VI. i Urban V. ANTE SEKULIĆ, Pregled povijesti pavlina, Kul- tura pavlina u Hrvatskoj, 1244. - 1786., katalog izložbe (Zagreb, Muzej za umjetnost i obrt, 12. svibnja - 31. listopada 1989.), Zagreb, 1989., 31-39: 32. Marija Mirković navodi da je riječ o Ivanu XXII. ili Klementu V. MARIJA MIRKOVIć, 1979., (bilj. 5), 28; MARIJA MIRKOVIĆ, 1995., (bilj. 5), 90, 92. Pugelnik smatra da scena prikazuje dva povijesno odvojena događaja, odnosno donošenje Pravila sv. Augustina pavlinima preko papinskog izaslanika kardinala Gentilisa i svečano objavljivanje potvrde reda od pape Ivana XXII. Usp. tomislaV pUGelNik, 2008., (bilj. 8), 482. Nijedan od autora ne spominje papu Urbana V.

62 PetAr puhmajer, 2014., (bilj. 40), 247.

63 Isto, 247.

64 Isto, 247.

65 Isto, $257-258$.

66 To je važno istaknuti jer je prilikom obnove prostorije ljekarne u sjevernom krilu samostana izveden svod, čiji bridovi ne prate rub zidnog oslika, kao što je to izvorno bio slučaj, nego su napravljeni proizvoljno, pa sada postoje veliki i nejednaki razmaci između slikanih površina i bridova svoda.

\section{Abstract}

Petar Puhmajer, Bernarda Ratančić

SUMMER REFECTORY OF THE PAULINE MONASTERY IN LEPOGLAVA - CREATION, DESTRUCTION AND RETRIEVAL

The paper aims to analyze the history of the creation and later developments of the summer refectory in the Pauline monastery in Lepoglava. The refectory, or a dining room, was the monastery's largest room formed by the construction of the west wing in the 17th century, and lavishly decorated with stucco and wall paintings in the 18th century. When the monastery was turned into a prison in the 19th century, it lead to its long-time degradation, first due to its inappropriate use and then due to the collapse of the vault in the earthquake of 1880 . This period also saw the earliest efforts for its preservation, in the sense of documenting, researching and artistic evaluation, which we can see in the works of Ivan Kukuljević Sakcinski and Izidor Kršnjavi, and notably in the work of Ferdinand Quiquerez who made an aquarelle drawing of the entire stucco- and wall-painting design of the refectory. Subsequently, the room was badly damaged in World War II when, after the demolition of the upper floors, it was left in the open air. Until the beginnings of the 21st century, the refectory's wall decoration was thought to be lost, however, the conservation research has revealed the Pauline benefactors" portraits on the walls, painted lunettes and the walled-up grotta with stucco statues. The paper also discusses the research results, as well as the guidelines for the refectory's restoration.

KEYwORDS: architecture, wall painting, Lepoglava, Pauline monastery, summer refectory, $18^{\text {th }}$ century, baroque, destruction, renewals, conservation research 